\title{
Donald Trump Yönetimi Politikalarının Tarihsel Açıdan Değerlendirilmesi: Andrew Jackson Dönemi ile Bir Karşılaştırma
}

\author{
Assessment of Donald Trump Administration's Policies Historically: A Comparison with \\ the Andrew Jackson Era
}

\section{Şener Çelik ${ }^{1}$ (I)}

Öz

Amerika Birleşik Devletleri'nin 45. Başkanı Donald J. Trump, göreve geldiği tarihten bugüne iç ve dış politikada muhafazakar/ sağ bir duruş benimsemiştir. Bu duruş doğrultusunda, ülkedeki göçmen veya sığınmacılara karşı yabancı düşmanlığına varan ayrımcı uygulamalara girişmiş; kuvvet kullanma konusunda, sert retoriğine rağmen askeri müdahalelerden kaçınmış; uluslararası ticarette ise korumacı bir politika takip etmiştir. Trump, ABD'deki akademik çevrelerde ve medyada son dönemde bu özellikleri nedeniyle ülkenin 7. Başkanı Andrew Jackson ile karşılaştırılmış, ülkenin iç ve dış politikasının Jacksoncu yaklaşım olarak tanımlanan bir eksene kaydığı iddia edilmeye başlanmıştır. Jackson, Kuzey Amerika Yerlilerine karşı izlediği düşmanca politikalar nedeniyle yabancı düşmanlığıyla suçlanmış; kuvvet kullanmaktan kaçınması nedeniyle de tecritçi ve müdahale karşıt bir lider olarak tanınmıştır. Öte yandan, uluslararası ticarete yaklaşımı liberal bir çizgiye yakın olmuştur. Bu çalışmada, iki devlet adamı, yabancılar politikası, kuvvet kullanma politikası ve uluslararası ticaret politikası bağlamlarında karşılaştırılarak, aralarındaki benzerlik ve farklılıklar incelenmiş, günümüz ABD politikalarının tarihsel perspektiften değerlendirilmesi amaçlanmıştır.

\section{Anahtar Kelimeler}

Jackson, Trump, Muhafazakarlık, Tecritçilik, Yabancı düşmanlığı, Müdahale karşıtlığı

\begin{abstract}
Donald J. Trump, the 45th President of the United States of America, has adopted a conservative/right wing stance in domestic and foreign policy since his inauguration. In line with this stance, he embarked on discriminatory practices that led to xenophobia towards migrants and asylum seekers in the country; avoided military intervention in spite of his harsh rhetoric on the use of force abroad; and followed a protective policy in international trade. Trump has recently been compared to the 7th President, Andrew Jackson, in American academic circles and media, claiming that the country's domestic and foreign policy shifted to an axis defined as the Jacksonian approach. Jackson was accused of xenophobia because of his hostile policies towards North American Indians; and was recognized as an isolationist and non-interventionist in avoiding the use of force. On the other hand, his approach to international trade was close to a liberal attitude. In this study, the similarities and differences between two statesmen were examined in terms of foreigners' policy, use of force policy and international trade policy, so that, it aimed to evaluate contemporary United States policies from a historical perspective.
\end{abstract}

Keywords

Jackson, Trump, Conservatism, Isolationism, Xenophobia, Non-interventionism 


\section{Extended Summary}

Donald Trump has been one of the most controversial political leaders in the world since November 2016, when he was elected as $45^{\text {th }}$ President of the United States, both for his personal character and for his conservative right-wing vision. Although he came from the business world, he challenged the ruling and business elite, which is called 'the establishment', at every opportunity, and displayed an attitude that could be called opposing to mainstream media. Trump, who founded his political philosophy and rhetoric on 'America First' and 'Make America Great Again' slogans, signaled that he would be an actor who would make radical changes in domestic and foreign policy before he took office, and did not hesitate to explain that he would pursue a policy based on American exceptionalism and isolation. His actions, after winning the election, were essentially in harmony with this discourse.

The xenophobia that increased in the country with the strengthening of the white supremacist conservative ideology goes back to the Civil War period, especially after 9/11 in the United States, and the reaction against globalization and liberalism in the international arena played an important role in the election of Trump. Under these circumstances, Trump first attracted attention with his exclusionary and alienating attitude towards immigrants and asylum seekers living in the country. With the socalled travel ban, he tried to prevent the entry of Muslims and Latin Americans into the country, and attempted to end the program known as DACA, which allowed children, whose parents had entered the country illegally, to work and go to college. In line with this exclusionary and isolationist behavior in domestic politics, Trump stepped out of international agreements in which the United States was a party, cut-off relations with regional trade unions such as NAFTA and TPP, and entered an endless trade war with China. In the Middle East, the Trump Administration considered non-state actors as partners in the war against ISIS, but avoided military intervention in the region directly. Within the scope of this strategy, for instance, it provided training and equipment to the separatist Kurdish terrorist organization PYD/YPG in Syria, while never using military force in the combat zone.

Due to these introverted populist policies, Trump has recently begun to be compared with the 7th American President Andrew Jackson in American political science and International Relations circles. Although Jackson, one of 29 American Presidents of military origin, naturally had a very different agenda and problems between 1829 and 1837 , it can be said that there are surprising similarities between the two leaders' world views. Jackson, like Trump, was not a leader of tolerance toward strangers. In 1830, he forced North American Indians to emigrate from their eastern regions to the west and pursued a policy that killed thousands of Indians during the deportation known as Indian Removal. Although he was an officer who had risen to the rank of general, the United States under his Administration did not engage in wars and always avoided military intervention aboard. The only event that the federal government enacted a law on the use of force during Jackson's period was, interestingly, not a foreign country, but South Carolina, which planned to leave the union. Although the Jackson Administration never used force on South Carolina, it managed to dissuade the state from its separatist policies with threat of using force. On the other hand, Jackson's departure from Trump 
was the importance he placed on international trade. During his adminitration, the United States signed commercial agreements with a number of countries, including the Ottoman Empire, the Russian Empire and Britain.

Undoubtedly, Jackson and Trump are two important political figures in the United States, with similarities and differences. In this study, the similarities and differences between the two statesmen were examined in terms of foreigners policies, the use of force and international trade policies, showed that they have parallel world views and policy practices in terms of xenophobia and non-interventionism, while they differ in international trade policies. In fact, it is unlikely to find an absolute resemblance between the political priorities of Trump, a political leader in the era of globalization, and Jackson's political agenda in the nineteenth century, when this concept was not yet in dictionaries. In this article, it was found that the two leaders have a parallel political paradigm in certain aspects, but based on this determination, it would not be right to define the current Administration in the United States as completely Jacksonian. Trump and Jackson were populist leaders with similar worldviews and political activities, surprisingly, with 179 years between their adminstrations. However, it would be extremist to conclude that there is an absolute congruence between the two leaders' domestic and foreign policies and that the United States has time traveled back to the Jacksonian era today. 


\section{Donald Trump Yönetimi Politikalarının Tarihsel Açıdan Değerlendirilmesi: Andrew Jackson Dönemi ile Bir Karşılaştırma}

Amerika Birleşik Devletleri’nin (ABD) 45. Başkanı Donald J. Trump, seçim kampanyasını ve Başkan seçildikten sonra izlemeye başladığı iç ve dış siyaseti, pek çok gözlemci ve yorumcuya göre 'aşırılıkçı' olarak nitelendirilebilecek bir muhafazakar söylem üzerine inşa etmiştir. Trump Yönetimince benimsenen bu politikaların, esasen özgün ve yeni olmadığı, fikirsel köklerinin ABD’nin 19. yüzyılda izlediği siyasi tercihlere ve ahlaki kabullere dayandığ 1 , son dönemde özellikle Amerikan siyaset bilimi ve Uluslararası İlişkiler çevrelerinde tartışılmaya başlanan bir konudur. Bu bağlamda, Trump'ın benimsediği popülist ve milliyetçi sağ söylem ve bu yönde gerçekleştirdiği icraatlar, 1829-1837 yılları arasında görev yapan ABD'nin 7. Başkanı Andrew Jackson'ın politikalarıyla karşılaştırılmaya başlanmış, iki liderin siyasi anlayışları arasında güçlü bir paralellik olduğuna yönelik iddialar, halen süregelmekte olan canlı bir tartışma yaratmıştır. Akademi içinde gittikçe artan biçimde savunulmaya başlanan bu görüşe göre, Jackson'ın Amerikan ulusunun istisnailiğine olan inanc1; eski bir asker olarak kuvvet kullanmaya olan eğilimine karşın askeri müdahalelerden her zaman kaçınması; dönemin uluslararası ortamında diğer ülkelerle olan ticari ilişkilerin gelişimine önem vermesi; ve ülkenin kendi ulusal çıkarı için iç sorunlara odaklanılması gerektiği yolundaki anlayışı, bugün Trump'ın izlediği politikalarla büyük oranda örtüşmektedir.

Jackson'ın işbaşında olduğu süre boyunca gerçekleştirdiği icraatları, gerçekten, öncelikle ABD’nin iç meselelerine yönelik olmuştur. Jackson'ın başkanlık döneminde iktidarda olan Demokrat-Cumhuriyetçi Parti ${ }^{1}$, Kuzey Amerika kıtasında yaşamakta olan kabileleri kuvvet kullanarak göç etmeye zorlamış, bu politika doğrultusunda 1832-1838 y1lları arasında yaklaşık 45.000 Yerli, ${ }^{2}$ ülkenin doğusunda yaşadıkları bölgelerden batıya göç etmek zorunda kalmıştır. Yerli Tehciri (Indian Removal) ${ }^{3}$ olarak bilinen olay çerçevesinde göçe tabi tutulan 18.000 Cherokee Yerlisinden 4.000'i yolda hayatını kaybetmiştir ki, bu sayıya, zorla yerlerinden edilen diğer beş kabile olan Seminole, Creek, Choctaw, Potawatomi ve Chickasaw’un uğradığı kayıplar dahil değildir (Thorntorn, 1992, s.74). Jackson, Başkan olduğu dönemde federal hükümetle Güney Carolina eyaleti arasında 1828 yılında konan gümrük vergileri nedeniyle çıkan krizde ise eyalete karşı kuvvet kullanılabileceğini savunmuş, dahası, bu yönde bir yasanın çıkarılmasına da öncülük etmiştir. Kriz, 1833’te yeni bir gümrük vergisi yasası çıkarılması ile sonuçlanmışsa da, alanyazında Fesih Krizi (Nullification Crisis) olarak bilinen olay, Jackson'ın gerektiğinde federasyon sınırları

1 Demokrat-Cumhuriyetçi Parti (Democratic-Republican Party), Thomas Jefferson ve James Madison tarafından, Alexander Hamilton'ın temellerini attığı Federalist Parti'ye muhalefeten 1792'de kurulmuştur. Monarşiyi çağrıştırdığı gerekçesiyle federal hükümetin merkeziliğine karşı bir görüşü temsil eden parti, faal olduğu dönemde kısaca Cumhuriyetçi Parti olarak adlandırılsa da, 1854’te kurulan bugünkü Cumhuriyetçi Parti ile karıştırılmamalıdır.

2 Kuzey Amerika kıtasında yaşayan yerli halk, alanyazında 'Native Americans', 'Indians', 'Indigenous Americans' gibi tanımlarla ve baş harfleri büyük olacak şekilde yazılarak isimlendirilmektedir. Makale içinde bu grupları ifade etmek için 'Yerli' ismi kullanılmıştır ve baş harfi büyük olarak yazılmıştır.

3 Olay, ABD akademik çevrelerinde ve resmi yazında Yerlilerin 'yerinden edilmesi' (removal) kavramıyla tanımlanmaktadır. Vaka hakkında ABD devlet açıklamalarında ya da siyaset bilimi veya tarih alanyazınında hiçbir zaman 'tehcir' anlamına gelen 'relocation' veya 'resettlement' kelimeleri kullanılmamıştır. Ancak, olayın hukuken ve fiilen açıkça bir tehcir uygulaması olması nedeniyle, bu vaka Türkçe kaynaklarda ve medya mecralarında genellikle 'Kızılderili Tehciri' olarak anılmaktadır. Bu araştırmada, anlam karmaşasından kaçınmak ve fiili doğru tanımlamak adına, 'Indian Removal' kavramının 'Yerli Tehciri' olarak ifade edilmesi uygun görülmüştür. 
içinde kendi halkına karşı silahlı bir angajmana girebileceğini göstermesi açısından ilgi çekicidir. Öte yandan, bu şahin davranışıyla çelişkili biçimde, Andrew Jackson'ın dönemin ordusunda general rütbesine kadar terfi etmiş emekli bir subay olmasına rağmen, başkanlığ1 süresince hiçbir önemli sınır ötesi askeri müdahaleye girişmemesi ve ABD'nin yabancı devletlerle olan ilişkilerini neredeyse bütünüyle ticaret anlaşmaları çerçevesinde yürütmesi de kuşkusuz dikkate değer bir husustur. Sözü edilen dönemde, Rus Çarlı̆̆ı, Osmanlı İmparatorluğu, İspanya, Büyük Britanya ve o dönemde adı Rattanakosin Krallığı olan Tayland'la ikili ticaret anlaşmaları yapılmış, özellikle bu son anlaşmadan sonra ülkenin ihracatı \% 75, ithalatı ise \% 250 oranında artmıştır (Latner, 2002, s.120).

$\mathrm{Bu}$ çalışmada ele alınan temel araştırma soruları, iki Başkanın izlediği politikalar arasında gerçekten bir benzerlik olup olmadığı, eğer var ise, bunların hangileri olduğudur. İkinci bir araştırma sorusu ise, Trump Yönetimi ve Jackson Yönetimi arasında, benzerliklerin dışında herhangi bir ayrışmanın var olup olmadığıdır. Çalışmanın amacı, Trump Yönetimi'nin dış politikasını Andrew Jackson'ın başkanlık dönemi ile karşılaştırarak, alanyazında sıkça yer almaya başlayan iki liderin politikaları arasındaki benzerlik iddialarının ne derecede doğru olduğu hakkında bir sonuca ulaşabilmektir. Bu doğrultuda, Jackson ve Trump, yabancılara karşı izledikleri politikalar, kuvvet kullanma ve uluslararası ticaret ilişkileri dikkate alınarak karşılaştırılacaktır. Trump'ın iç ve dış politikada izlediği ileri sürülen muhafazakar, tecritçi ve tek taraflılık yanlısı politikaları, şimdiye kadar çeşitli bilimsel araştırmalarda farklı yöntemlerle incelenmesine rağmen, bu konuda tarihsel karşılaştırma yöntemi ile kapsamlı olarak gerçekleştirilen araştırmaların sayısı fazla değildir. ABD dış politikasını - ve potansiyel olarak dış politikayı etkileyebilme gücü olan iç politika konu başlıklarını - tarihsel perspektiften ele alacak olan bu çalışmanın, aktüel gelişmelere odaklanmak yerine, iki farklı tarihte göreve gelmiş iki Başkanı inceleyerek, günümüz ABD politikalarının daha iyi analiz edilebilmesine katkı sağlayabileceği değerlendirilmiştir. $\mathrm{Bu}$ amaç doğrultusunda, araştırma karşılaştırmalı yönteme (comparative method) göre yapılmıştır. Karş1laştırmalı yöntem, en yalın tanımıyla, olay ve objelerin farklılık veya benzerlikler ekseninde tarif edilmesi olarak tanımlanabilir (Çilliler, 2018, s.36). Sosyal bilimlerde karşılaştırmalı yöntemin bağımsız bir metot olup olmadığı hakkında bu alanda çalışan araştırmacıların farklı yaklaşımları olmuşsa da, bugün genel kabul gören görüş, yöntemin bağımsızlı̆̆ı yönündedir. Lijphart, karşılaştırmalı yöntemin, deneysel yöntem, istatistik yöntemi ve vaka çalışması yöntemi ile birlikte sosyal bilimlerde kullanılan temel yöntemlerden biri olduğunu belirtir (Lijphart, 1971, s.682). Ancak yazara göre, karşılaştırmalı yöntemin kullanımı, analiz edilecek vaka sayılarının düşük olduğu durumlarda ('small-N' olarak adlandırılan durumlarda) daha uygundur (Lijphart, 1971, s.684). Makalenin birinci bölümünde, Jackson'ın ve Trump'ın popülist olduğu ileri sürülen siyaset anlayışlarının benzerliğine dikkat çeken çalışmalar incelenerek, alanyazında bu konuda yer alan görüşlere yer verilecektir. İkinci bölümde, Jackson'in yabancı politikası, kuvvet kullanma politikası ve uluslararası ticaret politikası ele alınacaktır. Üçüncü bölüm, Trump Yönetimi’nin izlediği politikaların araştırılacağı bölümdür. Bu kısımda, ikinci bölümdekine paralel olarak, Trump'ın yabancı politikası, kuvvet kullanma politikası ve uluslararası ticaret politikası incelenecektir. Sonuç yerine yapılacak değerlendirmede ise, Jackson ve Trump'ın ele alınan konularda izledikleri politikalara bakılarak, siyasi anlayışlarının ve icraatlarının ne derecede benzediği veya ayrıştığı ortaya konmaya çalışılacaktır. 


\section{Alanyazında Jackson - Trump Benzerliği}

Siyaset bilimi ve Uluslararası İlişkiler alanındaki bilimsel çalışmalarda olgu, olay ve aktörler arasında karşılaştırma yapmak yaygın bir yöntemdir. Trump Yönetimi dış politikasının ABD tarihindeki bir diğer Başkan ile karşılaştırılarak incelenmesi de bu nedenle esasen çok da sıradışı bir yöntemi yansıtmaz. Bu metodolojik anlayıştan yola çıkan Hamilton, Trump'ın dış politikasını NATO ve güvenlik başlığı altında inceleyerek, Başkanın ittifak ilişkisine bakışını Jackson’ın ABD’nin çıkarlarını ön planda tutan yaklaşımına benzetmiştir. Trump, NATO üyesi ülkelerin Gayrisafi Milli Hasılalarından \% 2'lik bir payı savunma bütçeleri için ayırmalarını istemiş ve bu bütçenin \% 20'sini altyapı-donatım modernizasyonuna harcamaları gerektiğini savunmuş; ayrıca, NATO’nun faaliyetlerinde terörle mücadeleye özel önem verilmesi gerektiğini gündeme getirmiştir. Yazara göre, her iki talep de, dış politikada sürekli Amerikan çıkarlarını merkeze alan Jackson'ın politika anlayışına paraleldir (Hamilton, 2017, s.6). Birinci talep doğrultusunda, ABD’nin, ittifak içindeki mali külfet payını düşürmek suretiyle, kendi bütçesinden tasarruf etme olanağı bulacağı; üye ülkelerdeki modernizasyon çalışmalarını da Amerikan savunma sanayinde kar maksimizasyonu sağlamak ve kalifiye iş gücünde istihdam artışı yaratmak için kullanacağı açıktır. NATO'nun terörle mücadeleye daha fazla angaje olması ise, ABD'nin denizaşırı askeri operasyonlarında görece azalmaya neden olarak müdahalelerin yol açtığı ekonomik kayıpları ve daha önemlisi asker zayiatını azaltacaktır. Gerçekten, her iki talep de, aşağıda açıklanacak olan Jackson'ın uluslararası ilişkilerde askeri müdahalelerden çok ticari anlaşmalara önem atfettiği ve kuvvet kullanımında sınırlama öngören politikalarıyla benzerlik taşımaktadır. Bu açıdan bakıldığında, yazarın saptaması yerindedir.

Alanyazında, Trump dış politikasının sahip olduğu, veya olamadığı, 'büyük strateji' (grand strategy) açısından da Jacksoncu anlayışla benzerlik gösterdiği öne sürülmüştür. Cha'ya göre, Trump Yönetimi'nin dünya görüşü, Reagan sonrası Cumhuriyetçi Parti geleneklerinde görülmeye başlanan uluslararasıcılık, demokrasinin yayılması/geliştirilmesi ve göçmenlik taraflılığı politikalarına karşı gelen, alışılmışın dışında bir oluşumu temsil etmektedir (Cha, 2017, s.88). Yazar, bu yeni oluşumun belirgin biçimde Jackson'ın Amerikan müesses nizam karşıtlığına eşdeğer olduğunu iddia etmiştir ki, bu karşıtlık da, Trump'un kişisel olarak Washington'daki iktidar seçkinlerine karşı duyduğu güçlü şüphede ifade bulmuştur. ${ }^{4}$ Cha'nın analizinde, iki devlet adamının dış politika anlayışları, bir düşmanı tanımlarken kullandıkları 'onurlu' ve 'onursuz' kavramları açısından da koşutluk göstermektedir. Cha'ya göre, Jacksoncu etik, Amerikalıların 'barbar' düşmanlara verecekleri her karşılığ1 'masum' (innocent) olarak tanımlayarak meşrulaştırır ve bu mücadelede herhangi bir ahlak sınırı olması gerektiğini reddeder. Trump'ın, teröre karşı yürütülen savaşta düşmanları 'barbar' olarak nitelemesi ve bu kapsamda açıkça işkence anlamına gelen 'su tahtası' (waterboarding) gibi 'etkin sorgulama' (enhanced interrogation) uygulamalarını savunması da aynı anlayışı çağrıştırmaktadır (Cha, 2017, s.90).

4 Cha, burada dış politika seçkinlerini ve müesses nizamı vurgularken 'inside the Beltway' kavramını kullanmıştır. Sözlük anlamı 'çevre yolu' olan 'beltway', aynı zamanda Washington, D.C.'yi çevreleyen 64 mil uzunluğundaki otoyolu ifade eder. 'Inside the Beltway' ise, mecazi olarak, federal hükümeti, onun adına çalışan müteahhitleri, lobicileri ve genel olarak bunlarla işbirliği yaptığı varsayılan kurumsal ana akım medyayı temsil eden bir deyimdir. Yazar, Trump'ın bu çevrelere duyduğu antipatiyi ve güvensizliği, Jackson'ın aşağıda incelenecek olan politika anlayışının günümüzdeki izdüşümü olarak değerlendirmiştir. 
Trump Yönetimi’nin politik söylemleri ve icraatlarını inceleyen başka yazarlar da 2016 sonrası Amerikan dış politikasını neredeyse bütünüyle 'Jacksoncu geleneğin devamı' olarak tanımlamışlardır. Bunlardan ikisi olan Clarke ve Ricketts’e göre, Trump’ın vulgar bir tabirle Amerikan halkına 'kazık atıldığı'nı varsaydığı - 2. Dünya Savaşı sonrası uluslararası düzeninden koparmayı içeren dış politika ajandası bu benzerliği göstermesi açısından önemlidir. Başkan, iş başına geldikten sonra toplumdaki Jacksoncu kesimleri haklı kılacak şekilde bir tek taraflılık politikası benimsemiş, Amerika'nın 'ulusal onuru' (national honor) ve 'itibarı' (reputation) kavramlarını dayanak noktası aldığı 'Önce Amerika' (America First) mottosunu ortaya atarak bir çeşit slogan mühendisliği yapmıştır (Clarke ve Ricketts, 2017, s.373). Yazarlar, bu bağlamda, ABD’nin Birleşmiş Milletler İklim Değişikliği Çerçeve Sözleşmesi Paris Anlaşması'ndan (Paris Agreement Under the United Nations Framework Convention on Climate Change) çekilmesini bir örnek olarak vermişlerdir. Buna göre, Trump, Paris Anlaşması'nı ABD’nin ekonomik ve fiziksel güvenliğine tehdit olarak göstermek suretiyle, doğrudan Amerikan halkı ile [kamu güvenliği ve refah üzerinden] bir bağlantı kurmaya çalışmıştır (Clarke ve Ricketts, 2017, s.375). Böylelikle, uluslararası hukuk tarafindan belirlenen normlar ve kurallar düşmanlaştırılırken, Amerikan halkının bu sözde düşmanlık karşısında 'mağdur' olduğu iddiası çerçevesinde Jacksoncu bir popülist politika söylemi geliştirilmiştir. Gerçekten, bu söylemin icraata dönüşmesi sonucunda, 1 Haziran 2017'de, Trump, ABD'nin anlaşmadan çekileceğini resmi olarak duyurmuş ve anlaşmanın kuralları gereği çekilmenin 4 Kasım 2020'de tamamlanacağını açıklamıştır. ${ }^{5}$ Aslında, Clarke ve Ricketts, bu dış politika sorunlarını daha 2016 seçimi yapılmadan çok önce ortaya atmışlar, Trump'ın seçimi kazanması halinde, Jackson'ın benimsediği siyasi çizgiye yakın bir duruş sergileyeceğini iddia etmişlerdir. Yazarlara göre, bu tartışma uzun süredir iki temel dış politika sorusunun gündemde olmasından kaynaklanmıştır ki, bu sorular, (1) ABD’nin 2. Dünya Savaşı sonrası liberal uluslararası düzenine kefil olmasının kendine getirdiği maliyet ile kazançların ne derecede orantılı olduğu; (2) Bu düzenin sürdürülebilme olasılığı, daha doğrusu, sürdürülmesinin gerekli olup olmadığıdır (Clarke ve Ricketts, 2016, s.14). Bugüne kadar izlediği politikalardan açıkça anlaşılan da şudur ki, Trump Yönetimi’nin birinci soruya cevabı, maliyetlerin kazançlardan daha yüksek olduğu; ikinci soruya cevabı ise, bu düzenin sürdürülmesinin gerekli olmadığıdır. Gelinen noktada, ABD dış politikasının liberal uluslararasıcı gelenekten tek taraflılık ve tecritçilik yanlısı bir çizgiye savrulması da bu anlayışın kaçınılmaz sonucudur.

Trump'ın siyasal ideolojisinin Jacksoncu olduğu bizzat kampanyasında ve sonradan danışman kadrosunda yer alan görevliler tarafından da belirtilmiştir. Bunlardan biri olan Steve Bannon, Trump'ın göreve başlama konuşmasını değerlendirirken, “Andrew Jackson Beyaz Saray’a geldiğinden beri böyle bir konuşma duyduğumuzu düşünmüyorum. Bunun [konuşmanın] son derece Jacksoncu olduğunu görebilirsiniz. İçinde çok, çok derin bir vatanseverlik var." diyerek, Başkanın siyasi çizgisine dair daha ilk günden bir ipucu vermiştir (Bannon, 2017). Bahsedilen, gerçekten de güçlü, fakat agresif bir vatanseverliktir. $\mathrm{Bu}$ vatanseverlikte ifadesini bulan ise, dışa dönük liberal Amerikan

5 Paris Anlaşması'nın 28. maddesine göre, anlaşmadan çekilmek isteyen bir ülke, bu kararını yazılı olarak BM'ye ülke anlaşmaya üye olduktan en az üç yıl sonra yapabilmektedir. Anlaşmanın tam metni ve ilgili madde için bkz.: The Paris Agreement Under the United Nations Framework Convention on Climate Change, https://unfccc.int/process-and-meetings/the-paris-agreement/the-paris-agreement, Erişim tarihi: 30 Temmuz 2019. 
politikalarının değerleriyle tezat, içe dönük, sert, realist bir dünya anlayışıdır. Bu anlamda Trump'in gerçek bir Jacksoncu olduğunu savunan Jones ve Khoo da, Jacksoncu gelenekte Wilsoncu liberal bir uluslararası ahlakçılğın (international moralism) imkansız olduğunu öne sürerek, Trump'ın bu açıdan aslında tam da Jacksoncu görüşü temsil ettiğini iddia etmişlerdir (Jones ve Khoo, 2017, s.44). Trump'ın bu politika anlayışını bir ölçüde rasyonalize etme eğiliminde görünen yazarlara göre, özellikle Çin'in yükselişi ve Rusya'nın yayılmacılığı karşısında ABD'nin tutumunu Obama'nın çok taraflılık (multilateralism) politikası değil, Trump'ın Jacksoncu dünya anlayışına paralel olan tek taraflılık politikası şekillendirecektir (Jones ve Khoo, 2017, s.45). Esasen bu yorum da, Bannon'ın yorumunda olduğu gibi, Trump'ın Jacksoncu geleneğin bir devamı olduğunu savunması açısından dikkat çekicidir.

Jackson'la Trump'ı benzeştiren bir başka görüşe göre ise, ABD dış politikasının yakın gelecekte ne yöne evrileceği hakkında bir çalışma yapılırken üç faktörün dikkate alınması gerekmektedir $\mathrm{ki}^{6}$, dış politikada Jacksoncu geleneğin devamlılığı bunlardan biridir (Rood, 2017, s.3). Rood'a göre, Trump'ın iç politikası Jacksoncu özellikler göstermektedir ve bu durum dış politikada da belirleyici bir etken olma potansiyeline sahiptir. Bu çerçevede, 'Önce Amerika' sloganı doğrultusunda Amerikan çıkarcılığının öncelenmesi, çok taraflı (multilateral) sistemden geri adım atılmasına neden olmuştur. Trump'ın temsil ettiği uluslararası diplomasiye ahlaki ve ideolojik kaygılardan yoksun 'iş-gibi' (businesslike) yaklaşımı, çıkarcı politik yaklaşıma gayet muntazam biçimde uymaktadır. Bu bağlamda, 'Amerika Kalesi' (Fortress America) olarak tanımlanan korumac1, tahkim edilmiş ve içe dönük bir ABD, dünya sahnesinden olabildiğince uzakta kalarak sadece Amerikan çıkarları tehlikede olduğunda tepki verecektir (Rood, 2017, s.5). Gerçekten, aşağıda ilgili bölümde ele alınacağı üzere, Trump Yönetimi bütün sert retoriğine rağmen, Jackson dönemine benzer biçimde, yaşamsal çıkarları için bir tehdit hissetmediği sürece, en azından bu çalışmanın yazıldığı tarihe kadar, sınırlarının ötesinde bir askeri müdahaleye girişmemiştir. Afganistan'da cüzi miktarda artırılan asker sayısı, Suriye'de danışman olarak görevlendirilen birlikler, yurtdışındaki askeri üslerde zaten varlığını korumakta olan unsurlar ve Suriye’ye karşı 2018'de düzenlenen seyir füzeleri saldırısı dışında, Trump döneminde sınır ötesi bir görevlendirme veya denizaşırı bir operasyonel hareketlilik gerçekleştirilmemiştir.

Jackson'ın politikalarına geçmeden önce, bu kısımda son olarak, Jackson-Trump ilişkilendirmesinin sadece akademik alanda yapılmadığını, bu benzetmenin medyada ve popüler tarihçilik alanlarında da yer almaya başladığının altını çizmek önemlidir. Ed Kilgore, The New York Magazine'de yer alan makalesinde, Jacksoncu geleneğin diş politikada ittifaklardan kaçınmayı esas aldığını belirterek, Trump'ın da bu yönüyle eski başkana benzediğini iddia etmiştir (Kilgore, 2019). Jarrett Stepman The National Interest'te

6 Rood'un değerlendirmesine göre, bu faktörlerden birincisi, uluslararası sistemdeki ve ülke içindeki frendenge (checks-and-balances) mekanizması; ikincisi ise, ABD’nin 'iyiliksever hegemon' (benevolent hegemon) olarak görüldüğü nostaljik paradigmadır. Yazarın birinci unsur kapsamında kastettiği, devletin Yasama ve Yargı organlarının Yürütme erkini ne şekilde etkileyeceği ve uluslararası örgütlerin ve hukukun ABD dış politikası için ne ölçüde yönlendirici bir etken olabileceğidir. İkinci unsur kapsamında ele alınan problematik ise, ABD’nin 'iyiliksever hegemon’ kimliği doğrultusunda oynadığı uluslararasıcı rolü Wilsoncu müdahalecilik geleneği doğrultusunda sürdürülebilme olasılığı ile ilişkilidir. Rood, Trump Yönetimi dış politikasında bu faktörlerin belirleyici olacağını ileri sürmüş, üçüncü faktörün ise, yukarıda açıklanan Jacksoncu anlayışın dış politikadaki etkisi olduğunu iddia etmişstir. 
yayınlanan yazısında ise, Jackson'ın, kuvvet kullanmaktan kaçınmasına rağmen, dönemin donanmasına önem vermesini Trump'ın günümüz ABD Deniz Kuvvetleri'ni güçlendirme politikasıyla ilişkilendirmiştir (Stepman, 2017). Tarihçi Bradley Birzer de, In Defense of Andrew Jackson adlı kitabında, iki başkan arasındaki benzerliklere dikkat çekmiş, Jackson ve Trump'ın siyasetin dişından gelen karakterler olduğunu vurgulayarak, müesses nizama muhalefetlerini bu nedene bağlamıştır (Birser, 2018). Bu örneklerden de görüleceği gibi, ABD'de gerek akademi gerek aktüel yazında son dönemde iki lider arasında bir benzeşim kurulmaya çalışıldığı kesindir. Bu benzeşimin ne kadar doğru olduğu ise çalışmanın bundan sonraki bölümlerinde araştırılacaktır. Bununla birlikte, burada vurgulanması gereken bir husus, Trump Yönetimi politikalarının, özellikle dış politikasının, sadece tarihsel bir benzeşim üzerinden analizinin muhtemelen hatalı, veya en azından eksik sonuçlar verebileceğidir. Kendinden önceki pek Cumhuriyetçi Başkanlar gibi, Donald Trump da farklı çıkar gruplarının, ideolojilerin ve doktrinlerin yönlendirici etkileri altında kalmıştır. Bu yönlendirici etki yaratan unsurlardan biri, ve burada mutlaka hatırlatılması gereken, Hristiyan-Siyonist ve Evanjelik kadrolaşmanın ABD dış politika karar verme mekanizmaları üzerindeki etkisidir. (Fildiş, 2018, s.158). Bugün Trump Yönetimi politikalarında Jacksoncu tradisyonun rolü büyükse de, aşırılıkçı inanç ve ideolojilere dayalı bu kadrolaşmanın ve lobi çalışmalarının etkisi de gözardı edilmemelidir.

\section{Jackson Dönemi Politikaları}

ABD Silahlı Kuvvetleri içinde görev almış 29 ABD Başkanından biri olan Andrew Jackson, İskoç-İrlanda göçmeni Presbiteryen bir ailenin çocuğu olarak dünyaya gelmiş; Albany Hukuk Fakültesi'ne devam ederek, mezuniyetini müteakiben avukatlığa başlamış; sonradan girdiği orduda sahip olduğu askeri kariyer haricinde Temsilciler Meclisi Tennessee temsilciliğinden, aynı eyalette yargıçlık görevine kadar çeşitli yerel ve federal hükümet kademelerinde çalışmıştır. İktidarı döneminde 21 yaş üstü beyaz erkeklere oy hakkı verilmesi; Yürütme yetkilerinin Yasama'nın aleyhine genişletilerek hükümet içinde seçkinler tekeli olarak isimlendirilen yönetici elitin tasviye edilmeye çalışılması; ve yargıçların atanma yerine halk tarafından seçilmesi, popülist politikalarının örnekleri arasında sayılmaktadır. Jackson dönemi dış politikasına yön veren olaylar da, bu içe dönüklük anlayışına paralel olarak, genellikle ülkenin iç politika gündemindeki vakalardan oluşmuştur. Aşağıdaki kısımlarda, Jackson'ın yabancı politikası, kuvvet kullanma politikası ve uluslararası ticaret politikası incelenecektir.

\section{Yabancı Politikası: Dönemin Yabancı Sorunu Olarak Yerliler ve Yerli Tehciri}

ABD'de 'Yerli' ismi, ülke topraklarında, Hawaii ve Alaska haricinde yaşayan 573 'federal olarak tanınmış kabile’yi (federally recognized tribes) ${ }^{7}$ ifade etmek için kullanılan bir çatı kavramdır. Kökenleri, büyük olasılıkla asırlar önce Bering boğazından kıtaya geçen Asyatik kavimlere dayanan sözkonusu kabileler, ABD kurulduktan sonra federal hükümet tarafından yarı-bağımsız (semi-independent) statüsünde topluluklar olarak kabul edilmiş; bununla birlikte, bu statünün tanıdığı haklara aykırı olarak, tarihsel süreç içinde devlet güçleri tarafından çeşitli ayrımcılık, şiddet ve katliam politikalarının mağduru ve kurbanı

7 Bu sayı, İçişleri Bakanlığı'na bağlı Yerli işleri Bürosu (Bureau of Indian Affairs) tarafından açıklanmıştır. Farklı kaynaklarda farklı rakamlarla karşılaşmak olasıdır. Konuyla ilgili daha ileri bilgi için bkz.: Bureau of Indian Affairs, https://www.bia.gov/, Erişim tarihi: 1 Ağustos 2019. 
olmuşlardır. Zaman içinde sayıları maruz kaldıkları hastalıklar ve savaşlar neticesinde azalan Yerlilerin yarı-bağımsız statüsü 1871 Yerli Tahsisleri Yasası (Indian Appropriations Act of 1871) ile sona ermiş, bu tarihten sonra kabile mensupları 'dahili bağlı millet' (domestic dependent nation) statüsünde, kendileri için ayrılan ve 'rezervasyon alanı' (Indian reservation) adıyla bilinen bölgelerde yaşamaya başlamışlardır. ${ }^{8}$

Yerlilerin yaşadıkları bölgelerden Avrupalı koloniciler veya federal hükümet tarafindan kuvvet kullanılmak suretiyle uzaklaştırılmaları, esasen Jackson döneminden önce başlayan bir politikanın sonucudur. Yerli kabilelerinin göçe zorlanması fikri ilk olarak Thomas Jefferson'ın döneminde ortaya atılmış, James Monroe döneminde planlanmış, Andrew Jackson döneminde ise, 28 Mayıs 1830 tarihinde çıkarılan Yerli Tehcir Yasası (Indian Removal Act of 1830) ${ }^{9}$ ile resmi bir devlet politikasına dönüştürülmüştür. Yasa kapsamında, ilk olarak 1831 'de Mississipi eyaletinde yaşayan Chocktaw kabilesine bağlı 17.000 Yerli göçe zorlanmış, ardından diğer kabileler de 1838'e kadar devam eden süreçte, ülkenin doğu kesimlerinde yaşadıkları bölgelerden Mississipi Nehri’nin batısına tehcir edilmişlerdir (Manifest Destiny and Indian Removal, 2015). Tehcir, şüphesiz, Jackson döneminin yabancılara bakış açısını en belirgin biçimde ortaya koyan olaydır. Bu olayla ilgili dikkat çekici ve öncelikle vurgulanması gereken husus, Jackson'ın tehcir politikasını Yerlilere yapılan bir 'lütuf' olarak görmesi ve bunun erdemli bir davranış olduğunu savunmasıdır. Kendi bakış açısıyla, yerleşim bölgelerini terke zorlanan ve Beş Medenileştirilmiş Kabile (Five Civilized Tribes) ${ }^{10}$ olarak bilinen kabilelerin yerlerinden edilmesi, esasen onların iyiliği gözetilerek uygulanan ve tamamen yasaya uygun olarak gerçekleştirilen bir icraattır. Jackson, 6 Aralık 1830'da Kongre'de konuyla ilgili yaptığg konuşmada, bu uygulama sayesinde, ülkede 'birkaç vahşi avcı' tarafindan işgal edilmiş geniş toprakların kalabalık ve medeni bir nüfusa açılacağını; kuzeyde Tennessee ile güneyde Louisiana arasında kalan bölgenin beyaz yerleşimcilere verilerek güneybatı sınırının güçlendirileceğini belirtmiş; öte yandan, bu uygulamayla Yerlilerin de eyaletlerin [politik ve kültürel] etkisinden kurtulacaklarını; kendi bildikleri yolda mutlu olacaklarını, ${ }^{11}$ ve belki de böylelikle, zaman içinde 'vahşi' tabiatlarından arınarak bilgili, medeni ve Hristiyan bir topluluğa dönüşebileceklerini söylemiştir (Jackson, 1830). Bu görüş, açıkça, Amerikan toplumunun bazı kesimlerinde İç Savaş’tan önce toplumsal bir

8 Kıtada yaşamakta olan Yerlilerin tarihi ile ilgili daha ileri bilgi için bkz.: Jake Page, In the Hands of the Great Spirit: The 20,000-Year History of American Indians, New York: Free Press, 2004. Yerlilerin uğradıkları katliamların bir soykırım olduğunu savunan bir araştırma için bkz.: Benjamin Madley, An American Genocide: The United States and the California Indian Catastrophe, 1846-1873, New Haven: Yale University Press, 2017.

9 Yasanın tam ve özgün metni için bkz.: A Century of Lawmaking for a New Nation: U.S. Congressional Documents and Debates, 1774-1875, https://memory.loc.gov/cgi-bin/ampage?collId=1lsl\&fileName=004/ 1ls1004.db\&recNum=458, Erişim tarihi: 1 Ağustos 2019.

10 Bu kavram, Cherokee, Chickasaw, Choctaw, Creek (Muscogee) ve Seminole Yerlilerini ifade etmek için Avrupalı koloniciler tarafından ortaya atılmıştır. Sözü edilen kabileler, Hristiyanlık geleneklerine uyum, okur-yazarlık ve ekonomiye katılım gibi özellikleri gözetilerek 'medenileştirilmiş' olarak tanımlanmış, ancak kavram, içerdiği ayrıştırıcılık ve aşağılayıcılık açısından pek çok çevrede olumsuz karşılanmıştır. Konuyla ilgili eleştirel bir değerlendirme için bkz.: Charles Robert Goins, Danney Goble, James H. Anderson, Historical Atlas of Oklahoma, Norman: University of Oklahoma Press, 2006.

11 Jackson bu cümleye 'kaba geleneklerinin etkisiyle' (under their rude institutions) kavramını da ekleyerek aşağılayıcı bir dil kullanmıştır. Cümlenin gelişi ve anlam bütünlüğü göz önüne alındığında, 'institutions' kelimesini 'kurumlar' değil, 'gelenekler' anlamında kullanmış olması muhtemeldir. Bu dilbilimsel ayrıntı, Jackson döneminde Yerlilerin sahip olduğu örf ve adetlerin neredeyse kategorik olarak tümden 'medenileşmemiş' olarak kabul edildiğine işaret etmesi açısından önemlidir. 
karşılık bulmaya başlayan beyazların üstünlüğü öğretisinin (white supremacy) erken evresini çağrıştırmaktadır. Jackson, liberal demokrasiyi ABD’nin o günü ve geleceği için temel siyasi düzenleyici unsur olarak görmüş ve bu siyasi düzen içinde yaşamayan Yerlileri 'ilkel topluluklar' olarak değerlendirmiştir.

Jackson'un bu ideolojisi, yukarıda bahsedilen 1830 Yerli Tehcir Yasası ile hukuki bir zemine kavuşturulmuştur. Yasanın asli amacı, Avrupalı yerleşimcilere yeni bölgeler tahsis etmek adına Mississippi nehrinin doğusunu Yerlilerin elinden almak olarak özetlenebilir (Tunçdemir, 2013). Dönemin ABD ordusu da, sözkonusu yasaya dayanarak göçe zorlanan Yerliler üzerinde kuvvet kullanmayı meşru görmüştür. Tehcir politikası kapsamında yürütülen askeri harekatlardan sorumlu olan General Winfield Scott, Beş Medenileştirilmiş Kabile'den biri olan Cherokeelere hitaben yaptığı çağrıda, "Cherokeeler! Birleşik Devlet Başkanı beni buraya, kuvvetli bir orduyla, 1830 Yerli Tehcir Yasası'na ve 1835 New Echota Anlaşması'na ${ }^{12}$ uyarak, Mississippi'nin diğer tarafında kendilerine müreffeh bir yaşam kuran halkınıza katılmanızı sağlamak için gönderdi." diyerek, üstü örtülü bir kuvvet kullanma tehdidi yaptıktan sonra, Yerlilerin Amerikan ordusuna karşı silah kullanmamaları ve dağlara çekilip saklanmamaları gerektiğini söylemiş, aksi takdirde çatışmanın kaçınılmaz olacağını duyurmuştur (Scott, 1837). Bildiri, makul ve iyi niyetli görünen diline rağmen, açıkça görüleceği üzere tehditkar bir üslupla yapılmış, Yerlilerin tehcire boyun eğmemeleri halinde kuvvete başvurulacağı vurgulanmıştır. Tehcir sonunda, toplam 85 kabileden yaklaşık 250.000 Yerli yaşadıkları bölgeleri terketmek zorunda kalmış ${ }^{13}$, sadece Cherokee kabilesinden 4.000 kişi göç yolunda ölmüş veya öldürülmüştür (Valentine, 2018, s.17-s.33). Jackson'1n tehcir ile meydana gelen can kayılarından doğrudan sorumluluğu hukuki bağlamda tartışılabilir olsa da, Yerlilere karşı benimsediği söylem ve izlediği politika ile aleni bir yabancı düşmanlığı yaptığı sonucuna ulaşmak yanlış olmayacaktır. Michael Paul Rogin ve Howard Zinn gibi Amerikan muhaliflerinin başını çektiği entelektüel çevreler tarafından 'kültürel soykırım' (cultural genocide) yapmakla suçlanan ve 'Yerlilerin yokedicisi' (exterminator of Indians) olarak isimlendirilen Jackson'ın, izlediği tehcir politikasıyla, ABD’nin eşitlikçilik üzerine tesis edilmiş kurucu ilkelerine karşı gelen bir anlayışı temsil ettiği yönünde bir algı uyandırmaktadır.

Öte yandan, Jackson'ın Yerlilere karşı girişilen şiddet politikaları ile tezat teşkil edecek biçimde, Başkan olmadan çok önce aslında sorunla ilgili siyasi ve hukuki etik bir yaklaşım benimsediğini gösteren kanıtlar da vardır. Bunlardan biri, Jackson'a ait yazışmaların toplandığ yüksek rütbeli subaylarından General James Winchester'e yazılan mektuptur. Jackson, henüz Başkan seçilmekten çok uzakta olduğu bir dönemde kaleme aldığg1 10 Mayıs 1802 tarihli mektubunda, Tennessee valisinden Yerlilere uygulanan kötü muamele ile ilgili bir mektup aldığını; mektuptaki bilgilere doğru ise, Binbaşı Russle isimli bir subayın Yerli Kampları sınırına yakın dağlık bölgede kızılderilileri kanunsuz olarak yakalayıp öldürdüğünü belirtmiştir. Jackson mektubunda, "Yüksek tütbeli bir subayın bu kanunsuz hareketi ülkemizin yasalarını ihlal etmekte ve bizi bir Yerli savaşına sürüklemektedir.”

1229 Aralık 1835 'te federal hükümet ile Cherokee kabilesi arasında imzalanan ve kabilenin Georgia'nın güneydoğusundaki bölgeleri terkederek batıya göç etmesini öngören anlaşma.

13 Tehcir, Kuzey Amerika Yerlilerinin toplumsal belleğinde neredeyse bir tür seçilmiş travmaya neden olmuştur. Yerli kültürüyle ilgili anlatılarda, olayın 'Gözyaşı İzleri' (Trail of Tears) adıyla anılması da bunun bir göstergesidir. 
şeklinde bir ifade kullanmıştır (Jackson, 1802, s.296). Jackson Winchester'e hitaben kaleme aldığı mektubunda, konuyla ilgili başka bir subay olan albay McKinney’e de bir mektup yazdığını, sözkonusu vaka gerçek ise, Russle'ın tutuklanmasının gerekli olduğunu ve akabinde hızlı bir soruşturma ile mahkeme önüne çıkarılması gerektiğini vurgulamıştır. Jackson'ın mektubu yazdığı tarihin Başkan olmadan çok önceye dayanması sebebiyle siyasi bir sorumluluğu bulunmadığı için bu şekilde ifadeler kullanmış olabileceği iddia edilebilir. Ancak unutulmamlıdır ki, sözü edilen dönemde de nizami ve gayri nizamı güçlere tarafından Yerlilere karşı sistematik ve yaygın bir şiddet uygulanmaktadır, Jackson da bu nizami ordu güçlerinin bir üyesi durumundadır. Buna rağmen, Yerlilere karşı yürütülen yasadışı kuvvet kullanma politikasına muhalefet etmesi, en azından hayatının bir döneminde şiddeti sorunun çözümü olarak görmediği şeklinde yorumlanabilir.

\section{Kuvvet Kullanma Politikası: İç Savaş'ın Açılış Perdesi Olarak Fesih Krizi}

Jackson, yönetimde olduğu sekiz yıllık sürede hiçbir sınır ötesi veya denizaşırı askeri müdahaleye girişmemiştir. Dönemin tek kuvvet kullanma olayı, şaşırtıcı biçimde, yabancı bir devlete karşı değil, Güney Carolina eyaletine karşı silahlı güçleri seferber etmesi olmuştur. ABD İç Savaşı'ndan önce eyaletler ile federal hükümet arasında, özellikle mali konularda, farklı düzeylerde meydana gelen kutuplaşmalar yaşandığ 1 bilinmektedir. Bu kutuplaşmaların temelinde yer alan esas faktör, Washington'ın korumacı politikalarının eyaletlerin ekonomilerine olan olumsuz etkisidir. Kongre, henüz Jackson iktidara gelmeden önce, ABD ürünlerinin düşük fiyatlı yabancı ürünler karşısında daha rekabetçi olabilmesi için ithal talebini azaltmayı amaçlayarak bir takım koruma tedbirleri almış, 1828'de Başkan John Quincy Adams tarafından Koruyucu Gümrük Vergileri uygulamasını hayata geçirmiştir. Güneyli halk tarafından 'Nefretler Vergisi' (Tariff of Abominations) olarak adlandırılan bu uygulama neticesinde, güney eyaletleri, mamül mallarının çoğunu kuzeyden ithal ettikleri için daha fazla vergi vermek zorunda kalmışlar, ayrıca, ürettikleri ihraç ürünleri için de ek vergi ödemeye başlamışlardır. Bunun üzerine, Güney Carolina, federal hükümetin uyguladığı gümrük vergisi uygulamasını feshettiğini açıklayarak, Washington'1 birlikten ayrılmakla tehdit etmiştir. Fesih Krizi olarak bilinen bu olay, Andrew Jackson'ın birinci döneminde karşı karşıya kaldığı - ve esasen 33 yıl sonra çıkacak olan Amerikan İç Savaşı'nın habercisi olan - en önemli siyasi vakalardan biridir.

Kriz, Güney Carolina' daki pamuk üreticilerinin koruyucu gümrük vergilerinden olumsuz etkilenmesiyle başgöstermiştir. Eyalet meclisi, 1828'de Senato'ya bir bildiri göndererek, sözkonusu tartışmaya neden olan gümrük kanununun federal yetkilerin Anayasa'ya aykırı biçimde kullanılması anlamına geldiğini belirtmiş, bu nedenle uygulamanın feshedilmesini talep etmiştir (Brogdon, 2011, s.6). İlgi çekici olan ise, 'Güney Carolina Protestosu' (South Carolina Protest) olarak bilinen bildirinin, ilan edilmeden önce 'Güney Carolina Açıklaması' (South Carolina Exposition) başlığıyla bir rapor olarak, bizzat Jackson'ın Başkan Yardımcısı John C. Calhoun tarafından kaleme alınmış olmasıdır (Yoo, 1992, s.142). Böylece, bir Başkan Yardımcısı, önce örtülü ardından açık olarak, belki de ülke tarihinde ilk defa, görevdeki bir Başkana aykırı bir politikanın sözcülüğünü üstlenmiş; dahası, yine ilk defa ayrılıkçılık görüşünü dile getirerek ülkenin iç politikasıyla beraber dış politikasını da etkileyebilecek bir başkaldırı girişiminde bulunmuştur. Calhoun bir süre sonra parti içinden gelen baskıyla istifa etmek zorunda kalacak olsa da, bu olay, $\mathrm{ABD}$ iç politikasıyla ilgili bir vakanın ülkenin bekasını ve birliğini etkileyebileceğini göstermesi açısından önemlidir. Colhoun'dan cesaret 
alan Güney Carolina'deki milis güçleri federal hükümete başkaldırı maksadıyla silahlı kalkışma hazırlığına girişmiş, bunun üzerine harekete geçen Jackson da, Kongre'ye baskı uygulayarak, 2 Mart 1833’te eyaletlerden vergi toplamada kuvvet kullanımına cevaz veren yasanın kabul edilmesini sağlamıştır. Yasalaşmadan önce Kuvvet Teklifi (Force Bill) olarak bilinen, sonradan da bu isimle anılan 1833 İthal Ürünlerinden Vergi Toplamaya İlaveten Yardımcı Olma Yasası (An Act Further to Provide for the Collection of Duties on Imports), Başkana, açıkça, ülke içinde eyaletlere karşı silahlı kuvvetleri kullanma yetkisi vermiştir. Yasa’nın 1. Bölümünde, vergi toplama kanunlarının uygulanmasının imkansız hale gelmesi durumunda, Başkanın ABD kara ve deniz kuvvetlerini kullanabileceği belirtilmiştir (Force Bill, 1833, s.632). Böylece Jackson, yasa ile, genel olarak bütün eyaletlerde, özel olarak ise Güney Carolina'da federal hükümetin vergi toplama yetkisine karşı gelen; Yasama'nın kabul ettiği hukuki düzenlemeleri kendi yerel yasama erkinin inisiyatifi ile fesheden; ve en önemlisi, ABD’nin federal yapısından ayrılarak bağımsılığını ilan edecek olan bütün eyaletlere karşı silahlı kuvvetlerle mukabele edilmesini yasal kılan bir güce erişmiştir. Jackson'ın kuvvet kullanma kararlılığını siyasi bir tercihten çok Yasama'dan aldığı hukuki bir yetke ile, adeta gövde gösterisi yaparak sergilemesi sonucunda, Güney Carolina'daki eyalet liderleri geri adım atmıştır. Kongre de buna karşı, vergilerin 1842'ye kadar kademeli olarak \% 20 oranında indirilmesini öngören 1833 Uzlaşma Yasası'nı (Compromise Tariff of 1833) kabul ederek krizin son bulmasını sağlamıştır. Kuşkusuz, Fesih Krizi bu çalışmada bütün ayrıntılarıyla ele alınamayacak kadar karmaşı siyasi, mali ve askeri ayrıntılara sahip bir süreçtir. Burada belirtilmesi gereken, Jackson'ın savaş olgusunu yakından tanıyan eski bir asker olmasına karşın, belki de tam da bu yüzden, ülke içindeki veya dışındaki her krizde orduyu devreye sokma eğiliminde olmadığı; ancak, yeri geldiğinde kuvvet kullanmaktan kaçınmayan bir lider portresi çizdiğidir.

\section{Uluslararası Ticaret Politikası: Dış Politikanın Belirleyici Unsuru Olarak Ticaret Anlaşmaları}

Jackson dönemiyle ilgili çalışacak araştırmacılarının çoğunun dikkatini öncelikle çekecek olan husus, ABD’nin 1829-1837 döneminde diş ilişkilerini ağırlıklı olarak ticaret anlaşmaları üzerine tesis ettiği olacaktır. Jackson, iktidar dönemi boyunca, ülkesi ile Avrupa, Asya ve Yakın Doğu ülkeleri arasında ticaretin gelişmesine önem veren bir lider olmuştur. Çalışmanın sonunda verilen Tablo-1'de görüleceği gibi, Jackson döneminde gümrük vergisi ortalamaları \% 60'lar seviyesinden \% 18 'lere kadar düşmüştür. Bununla birlikte, Jackson'ın ticari ilişkilerle ilgili sorunları her zaman kolayca halledilen müzakerelerle çözdüğü de söylenemez. Özellikle Fransa ile ABD arasında Fransa'nın el koyduğu Amerikan ticaret gemileri ve alıkoyduğu denizcilerle ilgili gerginlik, Jackson'ın ilk döneminde ekonomik olduğu kadar diplomatik boyutu da olan uzun süreli bir sorun teşkil etmiştir. Fransa, Nisan 1796'da ABD’nin Britanya ile ticaret anlaşması imzalamasından hemen sonra, buna tepki olarak, İngiliz limanlarına giden veya İngiliz ürünleri taşıyan Amerikan ticaret gemilerine el koymaya başlamıştır (Sechrest, 2007, s.102). Jackson işbaşına geldiğinde öncelikle bu soruna eğilmiş, Fransa Misyon Şefi ${ }^{14}$ William C. Rives'1 kronik hale gelen bu krizi çözmekle görevlendirmiştir. Dönemin Dışişleri Bakanı Martin Van Buren ise, ABD ile Fransa arasındaki bu sorundan

14 Rives, o dönemin diplomasi geleneğinde 'Minister' olarak tanımlanan bir pozisyona sahipti. Çoğu kaynakta 'Misyon Şefi' olarak da anılan bu pozisyon, 2. Dünya Savaşı'ndan sonra kaldırılmıştır. 
kaynaklanan ilişkileri 'umutsuz' olarak nitelemiştir (Latner 2002, s.119-20). Rives, uzun bir pazarlık evresinin ardından, Fransa hükümeti ile anlaşmaya varmış; Fransa'nın 4 Temmuz 1831'de ABD’ye 25.000.000 frank ödemesini hükme bağlayan anlaşmanın imzalanmasını sağlamış (Thomas, 1976, s.51); Fransa'nın anlaşma hükümlerine tam olarak uymaması üzerine kriz 1835'e kadar sürmüş, Fransa'nın taahhütüne uymasıyla ancak o sene çözülebilmiştir (Latner, 2002, s.120).

Jackson dönemi ikili ticari ilişkilerinin en önemli örneklerinden bir diğeri ise Osmanlı İmparatorluğu ile yapılan ticaret anlaşmasıdır. ABD’nin Osmanlılarla olan ilk ilişkileri, aslında İmparatorluğa bağlı Trablus Vilayeti ile 1801-1815 yılları arasında gerçekleşen Berberi Savaşları ile başlamış, bu çatışma evresinden 1830'ların başına kadar geçen sürede iki ülkenin birbiriyle önemli bir ilişkisi olmamıştır. Bu nedenle, Jackson’ın girişimini, iki devlet arasındaki ilk resmi barışçıl ilişki teşebbüsü olarak yorumlamak yanlış olmayacaktır. Babıali Hükümeti ile bir seyrüsefer ve ticaret anlaşması oluşturmak için 12 Eylül 1829'da Jackson'dan tam yetki alan Charles Rhind, 8 Şubat 1830'da İstanbul'a varmasını müteakiben dönemin dışişleri yetkilisi Reis Efendi ile görüşmelere başlamıştır. Müzakere kapsamında, Reis Efendi, gümrük aşamasındaki \% 5'lik vergi oranının kabul edilmesi halinde anlaşmaya varılabileceğini belirtmiş, Rhind ise, sözleşmeye gizli bir madde konularak, diğer devletlerle yapılacak anlaşmalarda farklı oranlar uygulanacak olursa ABD'ye de bu oranın uygulanmasını istemiştir. Reis Efendi, önce bu gizli madde isteğine sıcak bakmamışsa da, pazarlık sürecinin ardından oluşturulan taslakta, ABD’nin diğer büyük devletlerle eşit görüleceği; aynı vergileri vereceği ve vatandaşlarının da Fransa ve Britanya vatandaşlarının ayrıcalıkları ile aynı olacağı; Amerikan gemilerinin Karadeniz'e ücretsiz ve bekletilmeden geçebileceği hususlarında mutabakata varılmıştır (Kayapınar, 2017, s.48-49). ${ }^{15}$

Jackson Yönetimi, Osmanlı İmparatorluğu ile imzalanan ticaret anlaşmasının ardından, aralarında Rus Çarlığı, İspanya ve Britanya'nın da bulunduğu pek çok ülkeyle benzeri anlaşmalar imzalamıştır. Anlaşmalar, o günün diplomasi ve iletişim imkanları göz önüne alındığında olağanüstü uzaklıktaki coğrafi bölgelere kadar yayılmış, ABD Güneydoğu Asya ülkeleriyle bile ticaret anlaşmaları imzalamaya başlamıştır. Bunlardan biri de, bugün Tayland olarak bilinen Siam'la 1833'te yapılan Siam ve Birleşik Devletler Dostluk ve Ticaret Anlaşması'dır (Treaty of Amity and Commerce between Siam and the United States). Jackson adına misyon şefi Edmund Robert, Siam Kralı Rama III adına ise Chau Phaya-Phraklang'ın imzaladığı anlaşmanın 3. maddesi uyarınca, Siam limanlarına girerek buralarda mal alımı veya satımı yapacak Amerikan ticaret gemileri, vergi yerine gemilerin boyutlarına göre saptanacak bir harç ödeyecek; 9. ve 10. maddelere göre ise, ABD Siam'la olan ticaretinde 'en çok gözetilen ulus' (most favored nation) statüsüne sahip olacaktır (Treaty of Amity and Commerce, 1833) ${ }^{16}$. Anlaşma, ABD’nin güneydoğu Asya bölgesindeki ticaret olanaklarını genişletmesi açısından önemlidir. Ayrıca, bu tarihten sonra Siam Krallığı'nda yabancı hükümet danışmanı statütüsünde bulunan İngiliz ve Fransızların yerini Amerikalıların almasına yol açması nedeniyle de ABD için diplomatik bir kazanım anlamına gelmiştir (Young, 2003).

15 Anlaşmanın tam metni için bkz.: Treaty Between the United States of America and the Ottoman Empire : Commerce and Navigation, https://archive.org/details/ldpd_11015515_000, Erişim tarihi: 5 Ağustos 2019.

16 Anlaşmanın tam metni için bkz: Treaty of Amity and Commerce between Siam and the United States, https://ipfs.io/ipfs/QmXoypizjW3WknFiJnKLwHCnL72vedxjQkDDP1 mXWo6uco/wiki/SiameseAmerican_Treaty_of_Amity_and_Commerce.html 
Jackson'ın ticari anlaşmalara verdiği önem, gerek 1830'da yaptığı Kongre birleşik oturumu konuşması, gerekse 1837 'de yaptığı veda konuşmasında bu konuya söylevlerinin ilk başlığı olarak geniş biçimde yer ayırmasından açıkça bellidir. Jackson, 1830 Kongre konuşmasının giriş kısmında, ABD ve ona ait Batı Hindistan ile Kuzey Amerika kolonileriyle Britanya arasında yapılan anlaşmaların yıllardır çözülememiş sorunları sona erdirdiğini ve tüm taraflar için kazançlı olduğunu söylemiş; Britanya kolonilerine ihraç edilen ürünlerin bundan böyle sadece İngiliz değil Amerikan gemileriyle de yapılacağını sağlayan sözleşmeler yapıldığını vurgulamış; Amerikan ticaret gemilerinin Karadeniz ticaretinden ve taşımacılığından dışlanması ile oluşan zararın 1829 Edirne Anlaşması (Treaty of Adrianople) sayesinde ortadan kalktığını ve Karadeniz' in kendilerine açıldığını belirtmiştir (Jackson, 1830). Jackson, benzer biçimde 1837 veda konuşmasının başında da, iktidarı boyunca yabancı ülkelerle ilişkilerin tatminkar anlaşmalara ve dostane bir karaktere dayandığını, bunun sonucu olarak da ticaretlerinin sürekli olarak büyüdüğünü ve bayraklarının dünyanın her köşesinde dalgalandığını söylemiştir (Jackson, 1837). Jackson, konuşmasında 'ticaret' (commerce) ve 'ticari' (commercial) kelimelerini farklı cümlelerde ve paragraflarda 8 defa kullanırken; buna karşılık, dönemin en önemli olaylarından olan Yerli Tehciri ile ilgili 'Yerli' (Indian) kelimesini ve Fesih Krizi'yle ilgili 'vergi' (tax) kelimesini sadece birer defa kullanmıştır. Sonuç olarak, bu konuşmaların da gösterdiği gibi, Jackson dönemi iç ve dış politikalarında belirleyici unsur genel anlamda ticaret olmuş; kuvvet kullanımı sadece ülke içinde eyaletlere karşı federal hükümetin zorlayıcı yetkesi dahilinde gündeme getirilmiştir. Yerlilere karşı izlenen dışlayıcı ve ayrıştırmacı tutum ise, yukarıdaki ilgili kısımda açıklandığı gibi, sözkonusu kabilelerin 'yararına' yapılan bir fiil şeklinde sunularak siyaseten ve ahlaken meşrulaştırılmaya çalışılmıştır.

Bu kısımı bitirmeden önce vurgulanması yararlı olabilecek son bir husus, Jackson'ın yukarıda gösterilmeye çalışılan farklı konularda takındığı ayrıştırıcı, korumacı ve bazen sertlik yanlısı politik tutumuna karşın, iç siyasette, özellikle iktidar mücadelesi kapsamında, daha tarafsız ve adil olduğudur. Bunun bir kanıtı, Correspondence of Andrew Jackson başlığını taşıyan ve çeşitli devlet adamlarıyla karşılıklı yazışmalar şeklindeki birincil kaynaklara yer veren eserde yer alan mektuptur. Dönemin Temsilciler Meclisi Üyesi George Kremer, Jackson'a yazdığı notta, dönemin Başkanı John Quincy Adams'ın çevresindeki kişilerin dönemin bir başka Temsilciler Meclisi Üyesi Henry Clay’in çevresi ile görüşmeler yaptıklarını; bu çevrelerin Jacskon'a karşı bir entrika içinde olduklarını; ve bunları kendisine bildirmesi gerektiğini iddia etmiştir. Jackson da buna karşı verdiği yanıtta, Adams'ın ülkenin Anayasal Başkanı olduğunu söylemiş ve böyle bir ihaneti gerektirecek bir icraat içinde olduğuna inanamayağını belirtmiştir. Jackson, öte yandan, Washington' daki yozlaşma ve entrikaların insanların iradelerine üstün geldiğini söylemiş, Clay' in [seçim yolsuzluklarıyla ilgili] soruşturmayı kapattığını ve bunun karşılığında otuz parça gümüş alacağını açıklamıştır. Jackson Clay’in bu rüşveti kimden alacağı açıkça belirtmemiş ancak mektubu şu cümleyle bitirmiştir: "Bu, kanaatimce, hükümetimizde kendini belli eden en bariz ve cüretkar yolsuzluktur; ve halk tarafindan muhalefet edilmezse açık ve doğrudan rüşvetin öncülüğünü yapacaktır.” (Jackson, 1825).

\section{Trump Dönemi Politikaları}

Jackson ve Trump'ı ilişkilendirilebilecek belirgin bir davranış paterni bulmak, temel bir politika doktrini veya strateji saptamak görece zor bir araştırmadır. Birbirlerinin ardılı 
olan Başkanların politikaları arasında dahi büyük farklar olabilirken, Jackson'dan 187 yıl sonra göreve gelen Trump'ın siyasi anlayışının birebir Jackson'la eşleştiğini savunmak ve bunu kanıtlayacak mutlak benzer olay ve olgular bulmak da elbette olası değildir. Burada yapılacak olan, çalışmanın girişinde de belirtildiği gibi, Trump Yönetimi’nin dış politikası ve bu politikanın iç politikadaki uzantılarını inceleyerek, alanyazında son dönemde Jackson'la yapılmaya başlayan ilişkilendirmenin ne derecede doğru olduğunu bulmaya çalışmaktır. $\mathrm{Bu}$ amaca ulaşmak için, Trump'ın dış ve iç politikada izlediği tutumlar incelenecektir. $\mathrm{Bu}$ kapsamda, yukarıda ele alınan başlıklara paralel olarak, yabancı politikası, kuvvet kullanma politikası ve uluslararası ticaret politikası incelenecektir.

\section{Yabancı Politikası: Seyahat Yasağı Uygulaması ve Yükselen Göçmen Karşıtlığı}

Trump'ın ülkede yaşayan göçmenlere, sığınmacılara ve ABD'ye yasal göçmen olarak gelmek isteyen bireylere ve topluluklara karşı hoşgörülü bir bakış açısı taşımadığı, daha göreve gelmeden önce yaptığı açıklamalardan anlaşılmıştır. Trump, 16 Haziran 2015 tarihli konuşmasında, Meksika sınırına bir duvar örülerek bu ülkeden gelecek yasadışı göçmenlerin önüne geçileceğini, üstelik bu duvarın maliyetinin de Meksika'ya ödetileceğini bildirmiştir (Reid, 2015). Göreve geldikten sonra da yabancılara karşı bu ayrımcı tutumunu sürdüren Trump, 13769 ve 13780 numaralı Başkanlık Kararnamesi (Executive Order) ile Ocak-Eylül 2017 tarihleri arasında kademeli olarak, Irak, İran, Libya, Somali, Sudan, Suriye, Yemen, Kuzey Kore ve Venezüella vatandaşlarının ülkeye girişini 90 gün süreyle yasaklayan ve kamuoyunda 'seyahat yasağı' (travel ban) olarak bilinen bir düzenlemeyi yürürlüğe sokmuştur. Adalet Bakanı Sally Yates'ın kararnamelerin yasal olmadığı nedeniyle karara uyulmaması gerektiğini açıklaması üzerine de, Trump, Yates'i o güne kadar yazılı Beyaz Saray açıklamalarında eşine az rastlanan, belki de hiç görülmeyen bir üslup kullanarak 'ihanet'le (betray) suçlayıp görevinden almış ve yerine Virgina Doğu Bölgesi Savcısı Dana Boente’yi atamıştır (The White House, 2017, para.4). Uygulamanın hayata geçirilmesini müteakiben meydana gelen protestolar sonucunda yasayla ilgili çeşitli düzeltme girişimlerinde bulunulmuş, bu kapsamda Yeşil Kart sahiplerinin yasağın dişında tutulacağı duyurulmuştur (Baker, 2017, para.2).

Hawaii, Washington ve Maryland'deki mahkemeler tarafından açılan yürütmenin iptali davası sonucunda uygulama bu eyaletlerde kaldırılmış, ancak Anayasa Mahkemesi tarafından Haziran 2018' de görülen Trump v. Hawaii davasında 4 redde karşı 5 kabul oyuyla karar yasal bulunmuştur (Supreme Court of the United States, 2018, s.2). Bununla birlikte, uygulama özellikle uluslararası hukukçular tarafından yasadışı bulunmuştur. Koh'a göre, uygulama kapsamındaki ülke vatandaşlarının daha önce ABD sınırlarında bir Amerikan vatandaşının öldürülmesi gibi bir suça karışmamış olmaları ve kararın yeni bir ulusal güvenlik tehdidine dayanmayışı gibi nedenlerle hukuka aykırıdır (Koh, 2017, s.423-424). Cohn ise, kararı taraf olunan uluslararası antlaşmalar açısından incelediği çalışmasında, ABD’nin bir uluslararası sözleşmeyi imzaladıktan sonra sadece o sözleşmenin taraflarından biri olmadığını, aynı zamanda Anayasa'ya göre bu sözleşmenin iç hukukun bir parçası haline geldiğini savunmuştur. ${ }^{17} \mathrm{Bu}$ nedenle, mahkemeler de zaten doğal olarak bu sözleşmelerden herhangi birine aykırı olan bir Başkanlık Kararnamesi’ni geçersiz kılmakla yükümlüdürler (Cohn, 2017, para.5). Trump Yönetimi, seyahat yasağı uygulaması ile açık biçimde belirli bir dil, din ve ırka mensup bireyleri ve grupları varsayımsal bir Amerikan kimliğinin dışında

17 Cohn bu iddiasını ortaya koyarken, ABD’nin taraf olduğu Uluslararası Medeni ve Siyasal Haklar Sözleşmesi'ni ve Her Türlü Irk Ayrımcılığının Ortadan Kaldırılmasına İlişkin Uluslararası Sözleşme’yi dikkate almıştır. 
tutma eğiliminde olduğunu ortaya koymuştur. Seyahat yasağı, bu kimlikle bağdaşmayan bireyleri, toplulukları ve kültürleri dışlayıcı bir anlayışın ifadesidir. Uygulama, üstü örtülü bir biçimde Amerikan uygarlığının farklılığı ve istisnailiğine gönderme yapan, diğer medeniyetleri aşağı gören, dahası, ABD’nin bizatihi kendisinin bir göçmenler ülkesi olduğu gerçeğini reddeden bir siyasi anlayışın ürünü gibi görünmektedir.

Trump'ın yabancılara karşı uyguladığı ayrımcılığı gösteren en önemli uygulamalardan biri de, göçmen çocuklarının ülkede kalmasına olanak veren Çocukken Gelenler İçin Tatbikatın Ertelenmesi Programı'nı (Deferred Action for Childhood Arrivals, DACA) iptal edeceğini açıklamasıdır. DACA, çocuk yaşta ABD’ye gelenlerin belirli şartlara uymaları halinde iki sene boyunca sınırdışı edilmeyeceklerine dair 15 Ağustos 2012 tarihinde Anavatan Güvenlik Bakanlığı'nın memorandumu ile yürürlüğe giren bir garanti uygulamasıdır. Uygulamaya göre, 16 yaşından önce ABD’ye gelen ve 15 Temmuz 2012 tarihinde 31 yaşından gün almamış kişiler, okula gitmeleri veya ABD Silahlı Kuvvetleri'nde görev almaları halinde sınırdışı işlemlerine tabi tutulmayacaklardır (Department of Homeland Security, 2012). Program sayesinde, göçmenlerin sadece sınırdışı edilme riskleri ortadan kalkmamış, aldıkları ücretlerde de bir iyileşme görülmüştür. Programla, o tarihe kadar ülkeye yasadışı girdikleri kabul edilen göçmenlerin istihdamı artmış, yaklaşık 250.000 göçmene iş olanağı yaratılacağı hesaplanmıştır (Nolan, 2016, s.98114). Trump Yönetimi, bu ekonomik ve sosyal yararlarına rağmen programın Anayasa’ya aykırı olduğunu ve uygulamayla ilgili olarak 10 eyalette dava açıldığını iddia etmiş, uygulamanın kademeli olarak sonlandırılacağını belirtmiştir. Konuyla ilgili yapılan Beyaz Saray açıklamasında, bundan böyle DACA kapsamına giren kişilere yeni çalışma izni verilmeyeceği, ancak uygulamanın 24 ay geçerli kalacağı, bu suretle Kongre'ye de program hakkında harekete geçmesi için bir olanak verileceği duyurulmuştur (Trump, 2017). Trump'ın DACA programını uygulamadan kaldırmaya yönelik açıklamaları Yönetim içinde doğal olarak destek bulmuş, aralarında Adalet Bakanı Jeffrey Sessions'ın da olduğu Cumhuriyetçi politikacılar Trump'a destek vermişlerdir. Bununla birlikte, Kongre, bu araştırmanın yazıldığı tarih itibarı ile, programın iptali için bir yasal düzenleme çıkarmayı başaramamıştır. Anayasa Mahkemesi de Yönetim'in program hakkında yaptığı inceleme başvurusunu reddetmiştir.

\section{Kuvvet Kullanma Politikası: Suriye Savaşı Çerçevesinde Devlet-Dışı Aktörlerin Kullanımı}

Trump, Ocak 2017'de göreve başladığı günden bu çalışmanın yazıldığı tarihe kadar olan süreçte, ABD Silahlı Kuvvetleri'ne bağlı hiçbir unsuru önemli bir sınır ötesi veya denizaşırı askeri müdahelede kullanmamıştır. Resmi olarak halihazırda yürütülen tek kuvvet kullanma eylemi, Irak Şam İslam Devleti’ne (IŞİD) karşı çeşitli ülkelerde yürütülen mücadeledir ki, bu mücadele de, esasen 11 Eylül saldırılarından hemen sonra Bush Yönetimi'nin Kongre'den aldığı Askeri Kuvvet Kullanma Yetkisi (Authorization for Use of Military Force, AUMF) ${ }^{18}$ çerçevesinde başlatılan terörle-küresel-savaş (waron-terror) operasyonlarının devamı niteliğindedir. ABD, Obama döneminde, özellikle Irak ve Afganistan savaşlarında verilen kayıplardan sonra Asya ve Ortadoğu'daki çatışmalarda doğrudan askeri müdahale yerine, bu bölgelerdeki çatışma sahasında

18 AUMF'nin tam metni için bkz.: https://www.govinfo.gov/content/pkg/PLAW-107publ40/html/PLAW107publ40.htm, Erişim tarihi: 7 Ağustos 2019. 
devlet-dışı aktörlerin kullanılmasına dayalı bir strateji izlenmeye başlanmıştır. Trump Yönetimi'nin güvenlik politikası, bu anlayışın devamı olarak tanımlanabilir. Yönetim'in güvenlik stratejisi, anılan bölgelerde seçilmiş vekiller (proxies) aracılığıyla dolaylı bir müdahale üzerine tesis edilmiş olup, bu çerçevede icra edilen en dikkat çekici girişim, IŞİD’e karşı yürütülen savaşta Suriye' de rejim karşıtı ayrılıkçı-terörist Kürt militanlarına yardım etmek olmuştur. ABD, Trump döneminde IŞİD’e karşı yürütülen askeri harekatta, Suriye'de PYD'nin (Partiya Yekîtiya Demokrat; Demokratik Birlik Partisi) silahlı kolu olan YPG'ye (Yekîneyên Parastina Gel; Halk Koruma Birlikleri) yapılan eğit-donat desteğini sürdürmüştür. Yönetim, her ne kadar belirli dönemlerde Suriye'den çekileceği yönünde açıklamalar yapmışsa da, Suriye Demokratik Güçleri (Syrian Democratic Forces, SDF) olarak bilinen ve büyük çoğunluğunu YPG'nin oluşturduğu örgütlenmeye yönelik yardım programını 1srarla devam ettirmiştir. Obama Yönetimi tarafından 2013 yılı sonunda başlatılan program, Trump döneminde YPG'ye zırhlı personel taşıyıcı hafif araçlar sağlanması ile sürdürülmüştür (Gordon \& Schmitt, 2017, para.1-2). Program kapsamında, 2017'de Suriye'de savaşan birliklere, YPG'nin adı verilmeden, savunma bütçesinden toplam 393 milyon dolarlık bir tahsisat ayrılmış, sağlanan silahların arasında 12.000 adet Kalashnikov otomatik tüfek, 60.000 adet Kalashnikov şarjörü ve 6.000 adet modeli belirtilmeyen makinalı tüfek olduğu açıklanmıştır (Çamlıbel, 2017, para.1-4). Savunma Bakanlığı tarafindan doğrulanmayan iddialara göre ise, temin edilen silah ve ekipmanın arasında AN/PVS-7B gece görüş sistemi, AN/PEQ-2 kızılötesi aydınlatıcı ve EOTECH holografik görüş sistemi gibi yüksek teknoloji sistemleri de bulunmaktadır (Snow, 2017, para.14). Burada vurgulanması gereken, elbette, IŞID ve PKK/YPG gibi oluşumların sadece birer 'devlet-dışı aktör' olarak tanımlanmasının, bu örgütlerin işledikleri insanlığa karşı suçlar göz önüne alındığından eksik kalacağıdır. Her iki örgüt de Suriye ve Irak’ta hedef gözetmeksizin düzenledikleri saldırılarda sayısız sivilin ölümüne yol açmış ve kuvvet kullanarak yüzbinlerce insanın Ülkesinde Yerinden Edilen Kişiler (Internally Displaced People) konumuna gelmesine neden olmuştur. Dahası, IŞİD ve PKK/YPG, aralarında Türkiye, Suriye ve Irak'ın da olduğu ülkelerde ciddi güvenlik ve toprak bütünlüğü sorunlarına yol açarak, krizin uluslararası barış ve güvenliği tehdit eden bir boyuta ulaşmasına yol açmışlardır ki, bu sorunlar çalışmanın yazıldığı tarihte halen çözüme kavuşmaktan çok uzaktır.

Trump Yönetimi, esasen PKK/YPG terör oluşumuna sağladığı eğitim ve donatım desteğini belirli bir kuramsal çerçeveye oturmuştur. Kökleri Obama Yönetimine dayanan belirli politika, strateji ve askeri konseptler, sözü edilen eğit-donat programlarının, kısmen de olsa, sağlam görünen teorik bir altyapıya sahip olduğunu ve belirli kavramların üzerine inşa edildiğini göstermektedir. Bu kavramlardan biri Arkadan Liderlik (Leading From Behind) politikasıdır ki, javram en yalın olarak silahlı kuvvetlere bağlı düzenli unsurları çatışma sahasına sokmadan, müttefik ve ortakların etkinliğini kullanarak politik ve askeri hedeflere erişme olarak tanımlanabilir. Kavramı ilk defa kimin, ne zaman, hangi bağlamda kullandığına dair kesin bir bilgi yoksa da (Rogin, 2011); Obama döneminde ortaya atıldığ1 ve ABD’nin güvenlik politikalarını planlama ve icra süreçlerinde geri planda durarak ön plana müttefiklerini getirme yaklaşmı olarak yorumlandığı bilinmektedir. İkinci bir kavram olan Ortaklık Kapasitesi İnşası Stratejisi (Building Partnership Capacity, BPC) ise, ittifakların güçlendirilmesi üzerinde durmuş, ittifak kavramını ise sadece devletletlerle sınırlamayan bir anlayış üzerine tesis etmiştir (Yarger, 2015, s.35). Bu bağlamda, henüz 
Trump Yönetimi işbaşına gelmeden önce, ABD ulusal güvenlik politikalarında vekil kullanımının önemi vurgulanmaya başlanmış, 'surrogate warfare' (naip veya vekil savaşı) kavramı çerçevesinde özellikle Ortadoğu'da girişilen müdahalelerin askeri, stratejik ve politik yükü farklı aktörlerin sorumluluğuna bırakılmaya başlanmıştır (Krieg, 2016, s.99).

Trump Yönetimi’nin ayrılıkçı Kürt milliyetçisi terör örgütü PKK (Partiya Karkerên Kurdistanê; Kürdistan İşçi Partisi)|i ile bağlantılı olduğu bilinen YPG'ye silah ve eğitim desteği sağlamak suretiyle IŞi̇D’e yönelik çatışmalarda ABD kuvvetlerini kullanmadan Kürt militan güçlerini bir vekil olarak sahaya sürdüğü ve bu suretle muhtemel Amerikan kayıplarını önlemek veya en azından asgaride tutmak istediği açıktır. YPG'ye sağlanan eğit-donat yardımı bu bağlamda değerlendirildiğinde, bu askeri yardımların, esasen Obama dönemimde başlatılan vekil kullanma stratejisi kapsamında yürütüldüğü anlaşılmaktadır. ABD’yi mevcut çatışmaların olabildiğince dışında tutmayı amaçlayan bu yaklaşımı, sözlük anlamında olmasa da, tecritçi anlayışın günümüz şartlarındaki uygulaması olarak yorumlamak yanlış olmayacaktır. Bu saptamalar göz önüne alındığında, Trump’ın benimsediği Suriye stratejisinin, ABD’nin hayati çıkarlarını öncelemek ve IŞṠंD veya Esad Rejimi kuvvetlerine karşı askeri bir müdahalede bulunmama (non-interventionsim) stratejisi üzerine kurulduğu öne sürülebilir.

\section{Uluslararası Ticaret Politikası: Ticaret Savaşları ve Korumacılığın Yükseliși}

Bu kısmın ayrıntılarına geçmeden önce, Trump'ın Başkan olmadan önceki iş yaşamına kısaca değinmek yararlı olabilir. Trump, bilindiği gibi, önceki pek çok Başkanın tersine, siyasetten gelen bir figür değil, 'kurumsal Amerika' (corporate America) olarak da tanımlanan ülkenin büyük ticari girişimleri çevresinde yetişmiş, garip bir şekilde bazen bu dünyaya muhalif bir tavır da sergileyen, bir işinsanıdır. Kariyerine babasının gayri menkul geliştirme şirketinde başlayan Trump, 1971'de bu şirketi The Trump Organization olarak yeniden düzenlemiş (Blair, 2015, s.250); 1990'larda bu girişimlerinden bazılarının iflasa sürüklenmesine rağmen 2009'da Chicago'da inşa ettiği Trump International Hotel and Tower kompleksi ile yeniden gündeme gelmiştir (Roach, 2015). Bu tarihten sonra adı tekrar iflas haberleriyle anılmaya başlayan Trump, 2010'lu yıllarda ticari marka olarak soyismini lisans anlaşmalarıyla farklı ülkelerdeki gayrimenkul projelerine vermeye başlamış, 2019 yılına gelindiğinde sadece bu isim hakkından yılda 59 milyon dolar kazanır hale gelmiştir (Aaron, 2017). Trump'ın ticari geçmişinde önemli yer tutan bu anlaşma, lisanslama ve yatırım projelerinin, politik yaklaşımını kendisine has bir 'anlaşma' (deal) kültürü üzerine kurmasında etkili olduğunu varsaymak yanlış olmayacaktır. Başkan bunu bizatihi kendisi vurgulamış, çeşitli basın mecralarında kendini bir 'devlet adamı'ndan (statesman) çok, bir tür 'işbitirici' (dealmaker) olarak gördüğünü belirtmiştir (Haltiwanger, 2019). İşdünyasının içinden gelen bir figür olarak Trump'ın uluslararası ekonomi, uluslararası ilişkiler, dış politika ve güvenlik gibi son derece karmaşık uzmanlık alanlarında geçmişindeki deneyimlerine dayalı bu yaklaşımı sergilediği görülmektedir. $\mathrm{Bu}$ yaklaşımın ne derecede başarılı olduğunu veya olacağını değerlendirmek için henüz erken olmakla birlikte, ABD'nin İran'la varılan anlaşmadan geri çekilmesi, Ortadoğu'da destek bulmayan bir barış planını gündeme getirmesi ve Afganistan'da Taliban'la süregelen görüşme ve pazarlık sürecinin belirsizliği, bu yaklaşımın işlevselliğine ve yararına dair kuşkuları artırmaktadır. Trump'ın Başkanlık seçiminden 2016' da zaferle çıkmasında rol oynayan etkenler ise, sözkonusu kişisel girişimcilik özelliklerinin yanısıra, 
ülkedeki seçmen tabanıyla ilgili kültürel faktörler ve ABD’nin ekonomik, siyasi ve hukuki dinamiklerinin oluşturduğu yapısal faktörler olmuştur (Kardaş, 2017, s.100-101). Bunların arasında en önemli olan, yapısal faktörler sınıfına giren ve Kardaş'ın 'medyaendüstriyel kompleks' şeklinde adlandırdığı olgudur. Buna göre, Trump'ın başarısının arkasında medya ile büyük ekonomik çevrelerin etkileşimi olarak ifade edilebilecek bu kompleks yapı gelmiştir. Ekonomi eliti ile ülkedeki aşırı sağ medya desteğinin Trump'ın seçimleri kazanmasında önemli bir bileşen olarak rol oynadığı, bugün kolay reddedilemeyecek bir gerçektir. (Kardaş, 2017, s.103-s.105).

Böylesine alışılmışın dışında bir kariyerden sonra Başkan seçilen Trump, uluslararası ticaret anlaşmalarını, henüz iş başına gelmeden önce, ülke ekonomisi için bir tehdit olarak gördüğünü açıklamış ve pek çok mecrada 'korumacı' (protectionist) ${ }^{19}$ olarak nitelenen politikalar izlemekten kaçınmayacağını gösteren sert bir söylem benimsemiştir. İşbaşına geldikten kısa bir süre sonra da, güçlü bir tecritçiliği çağrıştıran bu söylem pratikte karşılık bulmaya başlamıştır. Bu politika doğrultusunda, Trump Yönetimi, önce 23 Ocak 2017'de Trans-Pasifik Ortaklığı'ndan (Trans-Pacific Partnership, TPP) ayrıldığını duyurumuş (Presidential Memorandum, 2017); ardından, 30 Kasım 2018'de Kuzey Amerika Serbest Ticaret Anlaşması'nın (North American Free Trade Agreement, NAFTA) feshedilerek yerine Birleşik Devletler-Meksika-Kanada Anlaşması'nın (United States-MexicoCanada Agreement, USMCA) getirildiğini açıklamıştır (The Office of the U.S. Trade Representative, 2018). Trump Yönetimi, bu korumacı politikasını 'Önce Amerika' sloganı çeçevesinde kurgulanan bir yaklaşımla, ulusal güvenlik kaygısı kapsamında meşrulaştırmaya girişmiştir. Beyaz Saray Ulusal Ticaret Konseyi Direktörü Peter Navarro, çelik ve alüminyuma konulan gümrük vergilerinin adaletsiz bir ticaretle ilgili olmadığını, ulusal güvenlikle ilgili olduğunu belirtmiştir (Fernandez, 2018). Esasen, Başkan’ın ulusal güvenlik gerekçesiyle ithalata sınırlamalar getirme yetkisi bulunmaktadır. 1962 Ticaret Geliştirme Yasası'nın (Trade Expansion Act of 1962) 232. maddesine göre, Başkan, ABD’nin yaşamsal çıkarları söz konusu olduğunda, Yasama'ya danışma şartı olmadan belirli malların ithalatına yasaklama getirme yetkisine sahiptir (Trade Expansion Act of 1962, P.L. 87-794, 1962, s.877). Ancak, Trump'ın uygulamasının ne dereceye kadar ulusal güvenlik kaygısı ile izah edilebileceği tartışmaya açık bir konudur. Bu çalışmanın kapsam ve kısıtı gereği bu konu burada incelenmeyecektir.

Uluslararası ticaret alanındaki en önemli konu başlıklarından bir diğeri de kuşkusuz ABD’nin Çin'le olan sorunlu ilişkileridir. Trump, seçim kapmanyası sürecinde, ABDÇin ticari ilişkilerinde ülkesinin ciddi kayıplar yaşadığını, iki ülke arasındaki ticarette ABD aleyhine 500 milyar dolarlık bir açık oluştuğunu, bu nedenle Amerikan çıkarlarının korunmasına yönelik bir politika izlenmesi gerektiğini açıklamıştır (Trump, 2016, para.45). Kasım 2016'da yapılan ve Trump'ın zaferiyle sonuçlanan seçimlerden sonra, ABD gerçekten de özelde Çin'e karşı, genelde ise ticari ilişkisi olan hemen tüm devletlere karşı

19 Trump'ın korumacı politikalar izlediğiyle ilgili yorumlara örnek olarak bkz.: Reid J. Epstein, Colleen McCain Nelson, "Donald Trump Lays Out Protectionist Views in Trade Speech", The Wall Street Journal, June 28, 2016, https://www.wsj.com/articles/donald-trump-lays-out-protectionist-views-in-tradespeech-1467145538, Erişim tarihi: 7 Ağustos 2019. Trump seçilmeden önce izleyeceği muhtemel politikayı ABD'nin ekonomi politikası tarihi bağlamında değerlendiren bir analiz için bkz.: Binyamin Appelbaum, "On Trade, Donald Trump Breaks With 200 Years of Economic Orthodoxy", The New York Times, March 10, 2016, https://www.nytimes.com/2016/03/11/us/politics/-trade-donald-trump-breaks-200-yearseconomic-orthodoxy-mercantilism.html, Erişim tarihi: 7 Ağustos 2019. 
korumacı bir politika izlemeye başlamıştır. Ticaret savaşları (trade wars) olarak anılmaya başlanan olayların kronolojisi incelendiğinde, önce Çin'in, Aralık 2017'de yayınlanan ABD’nin Ulusal Savunma Stratejisi'nde 'stratejik rakip' (strategic competitor) olarak tanımlandığı; ardından, Şubat 2018'de Menkul Kıymetler ve Borsa Komisyonu (The Securities and Exchange Commission) tarafından Çinli Chongqing Casin grubunun Chicago Borsası'nı (Chicago Stock Exchange) satın alınmasını yasaklayan bir düzenleme oluşturulduğu; Mart 2018'de ise Çin'den ithal edilen çeliğe \% 25, alüminyuma ise \% 10 gümrük vergisi uygulanacağı açıklandığı görülmektedir (Wong, 2018, s.1-2). Buna karşılık Çin de, Haziran 2018'de 3 milyar dolar değerinde ABD ihraç malına ek gümrük getirmiş; aynı ay içinde ABD de Çin'den alınan 34 milyar dolar değerinde çeşitli kalemlerdeki mallara yeni gümrük tarifesi uygulamaya başlamış; Temmuz 2018' de ise Çin aynı tutarda ABD ihraç ürününün yeni gümrük vergisine tabi tutulacağını duyurmuştur (Goncalves vd., 2018, s.4). Aşağıda Çalışmanın sonunda verilen Tablo-2'de görüleceği gibi, Trump Yönetimi, gümrük vergilerini 2018 yılında artırmaya başlamış, Aralık 2017'de \% 1.5 seviyesinde olan ortalama gümrük vergi oranı, aynı yılın Aralık ayına gelindiğinde \% 3.5'e yaklaşmıştır. Bu artışların en büyük hedefi ise Çin'den ithal edilen çelik, alüminyum ve bu maddelerden üretilen güneş panelleri ve çamaşır makineleri olmuş, ardından, aynı yılın Mayıs ayında Kanada, Meksika ve Avrupa Birliği'nden (AB) ithal edilen çelik ve alüminyuma uygulanan gümrük vergileri de artırılmıştır. ABD ile Çin arasındaki ticaret görüşmeleri halihazırda devam etmekte ise de, Trump'ın bu görüşmelerde çok da uzlaşmacı bir tavır takınmadığı, pazarlık sürecini 'kazan-kazan' (win-win) türünde bir anlaşmadan çok 'zero-sum-game' (sıfır sonuçlu oyun) gibi gördüğü değerlendirilmektedir. Bu nedenle de, ABD’nin korumacı ticaret politikasının öngörülebilir bir gelecekte radikal bir dönüşümle tekrar liberal bir çizgiye oturtulacağını düşünmek gerçekçi olmayacaktır.

\section{Sonuç Yerine: Karşılaştırma ve Değerlendirme}

Amerikan siyasetinde Jacksoncu gelenek, eğer gerçekten öyle bir gelenek varsa, Jones ve Khoo'nun belirttiği gibi, Demokrat Parti içinde doğmuş, ancak, tuhaf bir şekilde, 20. yüzyılın ikinci yarısından itibaren Cumhuriyetçi karaktere bürünmüştür (Jones ve Khoo, 2017, s.43). Seçime bağımsız aday olarak giren Trump'ın dünya görüşü ve yukarıda açıklanan politikaları, bu gelenekleri içselleştiren Cumhuriyetçi Parti'nin geleneksel politika ajandası ile büyük ölçüde örtüştüğü içindir ki, sonradan bu partiden aday olmuştur. Öte yandan, Trump'ın sözü edilen muhafazakar görüşleri ile Jacksoncu geleneğin dünya görüşü arasında benzerlikler olduğu kadar ayrılıklar da vardır. Öncelikle, Jackson döneminin yukarıda açıklanan uluslararası ticaret politikası dikkate alındığında, Trump Yönetimi ile benzeşmeden çok bir ayrışmanın olduğu görülmektedir. Jackson, iktidarda kaldığı iki dönem boyunca, ABD’nin yabancı ülkelerle olan ticari ilişkilerini geliştirmeyi bir öncelik olarak görmüş, dış politikasını ağırlıklı olarak bu ilişkiler üzerine tesis etmiştir. $\mathrm{Bu}$ dönemde, ABD ile Britanya, Osmanlı İmparatorluğu ve Güneydoğu Asya ülkeleri arasında ticaret anlaşmaları yapılmış; Amerikan ticaret gemilerinin serbest dolaşımı ve Amerikan mallarını yabancı limanlara taşımaları için imtiyazlar alınmıştır. Trump ise, uluslararası ticarette korumacı bir politikayı benimsemiştir. Seçim kampanyasında kullandığ1 'Önce Amerika' sloganı doğrultusunda, istihdamı artırmak - ve bir ölçüde çalışan orta sınıfı siyasi tabanı olarak konsolide etmek - adına, Amerikan şirketlerini ülke içinde yatırım yapmaya teşvik etmiş, gümrük vergilerini artırmış, TPP ve NAFTA 
gibi bölgesel ticaret rejimlerinden ayrılmış veya bunları yeniden yapılandırmıştır. Daha önemlisi, Çin ile sıklıkla ticaret savaşları olarak adlandırılan çatışmacı bir ekonomik ilişkiye girerek, ithal ürünlerine yüksek tarifeler getirmeye başlamış ve böylece bu ülkeyle sonucu ve yararı belirsiz olan bir cepheleşmeye girmiştir. Bu nedenle, Jackson'la Trump arasında yabancı ülkelerle olan ticaret ilişkileri açısından bir benzerliğe rastlanabileceğini iddia etmek doğru olmayacaktır.

Jackson'ın yabancı kültürlere karşı, ticari çıkarı olan ülke ve uluslar hariç tutulduğunda, siyaseten ve ahlaken bir sempati duymadığı aşikardır. Kıta Yerlilerine karşı izlediği politika da bunun açık göstergesidir. İncelenen dönemde, pek çok kabile, 1830 Yerli Tehcir yasası doğrultusunda yaşadıkları bölgelerden uzaklaştırılarak, sonradan rezervasyon alanı olarak adlandırılacak bölgelere göç etmeye zorlanmış, bu uygulama sırasında binlerce Yerli hayatını kaybetmiştir. Jackson, Kuzey Amerika'ya Avrupa'dan gelen beyaz göçmenleri Yerlilerden üstün görmüş; kabile halinde yaşayan toplulukların federal hükümetin belirlediği bölgelerde ve statüde yaşamaları halinde mutlu olacaklarını iddia etmiş; hatta daha da ileri giderek, bu toplulukların zaman içinde Hristiyanlaşarak beyaz toplumla bütünleşebilecekleri gibi bir beklentiye girmiştir. Trump'ın yabancılara karşı yaklaşımı da bu dünya görüşünün izlerini taşımaktadır. Göreve geldiği ilk yıl seyahat yasağ1 düzenlemesini uygulamaya sokarak, özellikle Müslüman, Latin ve Güneydoğu Asya kökenlilerin ülkeye girişini engellemeye çalışması bunun en önemli örneğidir. Bazı eyaletlerdeki yerel mahkemeler tarafından yürütme iptal edilmişse de, uygulama Anayasa Mahkemesi tarafından Trump v. Hawaii davası sonucunda yasal bulunmuştur. Yabancılara karşı izledikleri politikalar değerlendirildiğinde, Jackson ve Trump'ın politikaları arasında güçlü bir benzerlik olduğu söylenebilir. Her ne kadar, ABD’nin incelenen dönemlerde yüzyüze kaldığı 'yabancı' kavramı ve sorunu birbirlerinden farklı ise de, iki Başkanın beyaz üstünlügüune yönelik bir anlayışı temsil etmeleri ve inanç özgürlügüüle çatışan irrasyonel bir Christendom (Hristiyan diyarı) faraziyesine dayanmaları açısından birbirlerine benzeştikleri varsayılabilir.

Jackson, metin içinde de belirtildiği gibi, ordudaki geçmişine rağmen iktidarı boyunca askeri müdahalelerden ve kuvvet kullanmaktan kaçınmıştır. Başkanlık dönemi boyunca $A B D$, sınır ötesi veya denizaşırı hiçbir önemli silahlı çatışmaya girişmemiş; diğer ülkelerin birbirleriyle yaptıkları savaşlara müdahil olmamış; hiçbir gerekçeyle doğrudan veya dolaylı kuvvet kullanmamıştır. Jackson'ın gerektiğinde silahlı kuvvetleri kullanabileceğini gösteren tek örnek, ilgi çekici biçimde, ABD’nin yabancı ülkelere değil kendi eyaletlerine karşı orduyu harekete geçirebileceğini gösteren Fesih Krizi olmuştur. Jackson döneminde çıkarılan yasal düzenleme, federal hükümete bağlı silahlı güçlerin gerekli durumlarda eyaletlere karşı kara ve deniz unsurlarının kullanılmasına cevaz vermiştir. Trump'ın kuvvet kullanımına olan yaklaşımı da, bazı açılardan farklılıklar gösterse de, Jackson'ınkine benzemektedir. Başkanlık döneminde, en azından bu araştırmanın yazıldığı tarihe kadar, önemli bir askeri müdahale olmamıştır. Suriye'de Esad güçlerinin muhaliflere karşı kimyasal silah kullandığı gerekçesiyle 2018'de Şeyrat Hava Üssü’ne düzenlenen füze saldırısı haricinde, ki sadece 59 adet Tomahawk seyir füzesinin kullanıldığ 1 bu saldırı kapsamlı ve planlı bir kuvvet kullanımından çok uzaktır, Trump Yönetimi silahlı kuvvetler unsurlarını herhangi bir çatışmada görevlendirmemiştir. Suriye ve Irak’ta IŞİD’e karşı izlediği strateji kapsamında, PYD/YPG gibi devlet-dışı aktörlerle 
ortaklık kurmayı tercih etmiş, böylelikle çatışma sahasında Amerikan askeri varlığını asgari düzeyde tutarak fiili bir savaşa girmemiştir. Bu yönüyle, Trump'ın müdahaleci olmayan bir politika izlediği ileri sürülebilir. Sonuç olarak, iki liderin, kullandıkları tüm sert retoriğe rağmen, ABD'yi silahlı bir çatışmanın doğrudan tarafı yapmama ve askeri müdahalelerden kaçınma politikası izledikleri değerlendirilmektedir.

İki Başkan arasındaki tüm bu benzerliklere rağmen, Jackson ve Trump döneminin kendilerine özgün siyasi, ekonomik, askeri, sosyal ve kültürel şartlara sahip olduğu muhakkaktır. Bu nedenle, bir benzerlikle beraber, ve belki de benzerlikten çok, bir farklılığın gözlemlenmesi easen kaçınılmazdır. Jackson'ın Yerli Tehciri sırasında izlediği politika o sırada zaten kıtada yaşamakta olan kızılderili kabilelerinin kuvvet yoluyla yaşadıkları bölgelerinden uzaklaştırılmasına dayalıdır. Trump'ın yabancı politikasınde suje olarak karşımıza çıkan ise ülkeye sonradan yasal veya yasadışı yollarla giren göçmen ve/veya sığınmacılardır. Her iki dönem ve her iki aktör, bütünüyle değişik özelliklere sahiptir. Yine benzer şekilde, Jackson'ın kuvvet kullanma girişimi, ülke içindeki o dönemde erken evresinde olan devlet sistemi içindeki federal-yerel çatışmasından kaynaklanmış; Trump'ın Suriye özelinde değinilen kuvvet-vekil kullanma stratejisi ise, bütünüyle farklı uluslararası dinamiklerin etkisinde gerçekleşmiştir. İncelenen dönemler, birbirleriyle ilişkilendirilmeleri açısından gerçek anlamda eşsiz ve emsalsizdir. Son olarak, her iki aktörün uluslararası ticaret politikasının içinde evrildiği şartların da esasen birbirlerinden önemli derecede ayrıştığını vurgulamak gereklidir. Jackson'ın dönemi, küreselleşme kavramından çok uzak; bölgesel ticaret anlaşması diye bir mefhumun sözkonusu dahi olmadığı; ve üretim ilişkileri ile dünya ticaretinin çok farklı ekonomik düzenmelerle yürütüldüğü bir zaman dilimidir. Buna karşın, Trump’ın iktidar olduğu dönemde belirleyici unsurlar ise, küreselleşme; TPP ve NAFTA gibi ticari rejimlerde ifadesini bulan bölgeselleşme girişimleri; ve tek kutuplu dünya düzeninde ABD’nin Çin'e karşı ekonomik üstünlük sağlama arayışından kaynaklanan bir korumacılıktır. Açıkça görüleceği üzere, her iki aktörün ve dönemin, kendi şartları altında biricik olma durumu sözkonusudur. Liderler ve incelenen tarihsel dönemler arasındaki ilgi çekici benzerliklerin yanında, oldukça güçlü bir farklığın da bulunduğu açıktır.

Sonuç olarak, Jackson ve Trump, iktidarları arasında yaklaşık iki asır olan birbirlerinden farklı karakter özelliklerine sahip siyasi liderlerdir. İçinde yaşadıkları tarihsel dönemlerin de, yukarıda açıklanan benzemezlik şartları çerçevesinde vurgulanmaya çalışıldığı gibi, birbirinden farklı politik, ekonomik, sosyal ve kültürel değişkenlerin rol oynadığ1 devirler olduğuna şüphe yoktur. Bu nedenle, iki Başkanın benzer dünya görüşleri ve politik icraatları olsa da, son dönemde özellikle Amerikan akademisinde iddia edildiği gibi aralarında bütünsel bir benzeşme de bulunmamaktadır. Akademik dünya, özellikle ABD'de, bazen nesnelliği sorgulanmaya açık, abartılı ve spekülatif argümanlar geliştirmeye yatkın olabilmektedir. Ancak, bu eğilimin çoğu zaman yanlış genellemelere varma riski taşıyacağı da unutulmamalıdır. Bu çalışmada, iki Başkanın dünya görüşleri ve siyasi pratikleri arasında, yabancı politikaları, kuvvet kullanma politikaları ve uluslararası ticarete yaklaşımları açısından ilgi çekici benzerlikler olduğu görülmüştür. Öte yandan, bu tip benzerliklerin keşfedilmesi heyecan uyandırıcı olsa da, ABD’de Trump Yönetimi'nin göreve gelmesiyle birlikte bir tür 'yeni Jacksonculuk' akımının oluştuğunu savunmak, bugün için tam olarak gerçeği yansıtmaktan uzak, radikal bir varsayım olacaktır. 
Hakem Değerlendirmesi: Dış bağımsız.

Çıkar Çatıșması: Yazar çıkar çatışması bildirmemiștir.

Finansal Destek: Yazar bu çalışma için finansal destek almadığını beyan etmiştir.

Peer-review: Externally peer-reviewed.

Conflict of Interest: The author has no conflict of interest to declare.

Grant Support: The author declared that this study has received no financial support.

\section{Kaynakça/References}

An Act Further to Provide for the Collection of Duties on Imports,https://www.loc.gov/law/help/statutes-atlarge/22nd-congress/session-2/c22s2ch57.pdf

Appelbaum, B. (2016). On Trade, Donald Trump Breaks With 200 Years of Economic Orthodoxy, The New York Times, https:/www.nytimes.com/2016/03/11/us/politics/-trade-donald-trump-breaks-200-years-economicorthodoxy-mercantilism.html

Baker, P. (29 January 2017), Travelers Stranded and Protests Swell Over Trump Order, The New York Times, https:/www.nytimes.com/2017/01/29/us/politics/white-house-official-in-reversal-says-green-card-holderswont-be-barred.html

Bannon, S. (2017). Steve Bannon Pushed Trump to Go Full Andrew, The Daily Beast, Jackson, https://www. thedailybeast.com/steve-bannon-pushed-trump-to-go-full-andrew-jackson

Birzer, B. (2018). In defense of Andrew Jackson. Washington, D.C.: Regnery History.

Blair, G. (2015). The Trumps: Three Generations That Built an Empire. New York, Simon \& Schuster

Brogdon, M. S. (2011). Defending the Union: Andrew Jackson's nullification proclamation and American Federalism. The Review of Politics, (73), 1-29.

Bureau of Indian Affairs, https://www.bia.gov/

Cha, T. (2017). The Return of Jacksonianism: the International Implications of the Trump Phenomenon. The Washington Quarterly, (39), 83-97.

Clarke, Michael, Donald Trump and American Foreign Policy: The Return of the Jacksonian Tradition, Comparative Strategy, (36), 366-379.

Clarke, M., \& Ricketts, A. (2016). Understanding the return of the Jacksonian tradition, Orbis, (2), 13-26.

Cohn, M. (16 March 2017), Evaluate New Travel Ban in Light of International Law, Jurist, https://www.jurist. org/commentary/2017/03/marjorie-cohn-international-law/

Compromise Tariff of 1833, https://fraser.stlouisfed.org/title/5860

Camlıbel, C. (December 23, 2017). Trump approves $\$ 393$ million weapons list for Syria, Hürriyet Daily News, http://www.hurriyetdailynews.com/trump-approves-393-million-weapons-list-for-syria-124634

Çilliler, Y. (2018). Siyasal Krizler ve Karşılaştırmalı Yöntem, 1. Bozok Siyaset Bilimi Kongresi, Geçmişten Günümüze Yerel, Bölgesel ve Küresel Krizler, 24-26 Ekim.

Epstein, R. J., \& Colleen, McCain N. (2016), Donald Trump Lays Out Protectionist Views in Trade Speech, The Wall Street Journal, https:/www.wsj.com/articles/donald-trump-lays-out-protectionist-views-in-tradespeech-1467145538

Force Bill, Public Law 22, 22nd Congress of the United States, 4 Stat. 632, https://memory.loc.gov/cgi-bin/ ampage?collId=1ls1\&fileName=004/1ls1004.db\&recNum=679

General Winfield Scott's Address to the Cherokee Nation, (1837), http://www.thomaslegion.net/ generalwinfieldscottsaddresstothecherokeenation.html

Goins, C. R, et.al. (2006). Historical Atlas of Oklahoma. Norman: University of Oklahoma Press.

Goncalves, S., et al., US -China Trade War: İmpact Assessment, (2018), Center for Global Trade Analysis, Department of Agricultural Economics, Purdue University, https://www.gtap.agecon.purdue.edu/events/ Short_Courses/2018/documents/Trade.pdf

Gordon, M. R., \& Schmitt, E. (May 9, 2017), Trump to Arm Syrian Kurds, The New York Times, https://www.nytimes com/2017/05/09/us/politics/trump-kurds-syria-army.htmlHaltiwanger, John, (2019), "Trump says he's a dealmaker, but the derailed Taliban talks are just the latest major negotiation he's bungled as president”, Businessinsider, https:/www.businessinsider.com/trump-says-hes-a-dealmaker-but-keeps-bungling-major-negotiations-2019-9

Hamilton, D. S. (2017), Trumps Jacksonian foreign policy and its implications for European security. Swedish Institute Of International Affairs, (2), 1-8.

Indian Appropriations Act of 1871, https:/www.law.cornell.edu/constitution-conan/article-2/section-2/ clause-2/indian-treaties

Indian Removal Act of 1830, https://memory.loc.gov/cgi-bin/ampage?collId=llsl\&fileName=004/lls1004 . db\&recNum $=458$

Jones, D. M., \& Khoo, N. (2017). Donald Trump and the new Jacksonians. Policy, (1), 42-49.

Kardaş, T. (2017). Trump and the media-industrial complex in American politics. Insight Turkey, 19(2). 
Kayapınar, S. (2017). 1830 Osmanlı-ABD Ticaret Antlaşması Öncesi Amerika'nın Diplomasi Girişimleri, Dumlupınar Üniversitesi Sosyal Bilimler Dergisi, (51), Ocak, 39-56.

Kilgore, E. (2019), The Heirs of Andrew Jackson, Intelligencer, http://nymag.com/intelligencer/2019/06/trumpmay-be-the-true-heir-of-andrew-jackson.html

Krieg, A. (2016). Externilizing the burden of War: The Obama Doctrine and the US Foreign Policy in the Middle East. International Affairs, 92-101.

Koh, H. H. (2017). The Trump administration and international law, Washburn Law Journal, (56), 413-469.

Latner, R. B. (2002). 'Andrew Jackson'; Graff, Henry (ed.), The Presidents: A Reference History, New York: Charles Scribner's Sons., 106-127.

Lijphart, A. (1971), Comparative politics and the comparative method. The American Political Science Review, (3), 682-693.

Madley, B. (2017). An American Genocide: The United States and the California Indian Catastrophe, 18461873, New Haven: Yale University Press.

Manifest Destiny and Indian Removal, https://americanexperience.si.edu/wp-content/uploads/2015/02/ Manifest-Destiny-and-Indian-Removal.pdf

Fernandez, H. (2018). Trump tariffs are about national security: Peter Navarro, Fox Business, https://www. foxbusiness.com/politics/trump-tariffs-are-about-national-security-peter-navarro

Page, J. (2004). In the Hands of the Great Spirit: The 20,000-Year History of American Indians, New York: Free Press.

Pope, N. G. (2016), The Effects of DACAmentation: The Impact of Deferred Action for Childhood Arrivals on Unauthorized Immigrants. Journal of Public Economics, (143), 98-114.

President Andrew Jackson's Farewell Address. (1837). https://millercenter.org/the-presidency/presidentialspeeches/march-4-1837-farewell-address

President Andrew Jackson's Second Annual Message to Congress, December 6, 1830, The American Presidency Project, http://www.presidency.ucsb.edu/ws/?pid=29472

President Andrew Jackson's Speech to Congress on Indian Removal, https://www.nps.gov/museum/tmc/ MANZ/handouts/Andrew_Jackson_Annual_Message.pdf

Presidential Memorandum Regarding Withdrawal of the United States from the Trans-Pacific Partnership Negotiations and Agreement, (2017), https://www.whitehouse.gov/presidential-actions/presidentialmemorandum-regarding-withdrawal-united-states-trans-pacific-partnership-negotiations-agreement/

Rood, J. (2017). America First: Trump and the Multi-Order, Epilogue Clingendael Strategic Monitor, 1-8.

Roach, D. (2015). We Condensed Donald Trump's Lifetime into a Simple Infographic,

https://www.businessinsider.com/donald-trump-career-timeline-history-2015-9

Rogin, Josh, Who Really Said Obama Was "Leading From Behind"? Foreign Policy, (27 October 2011), http:// foreignpolicy.com/2011/10/27/who-really-said-obama-was-leading-from-behind/

Sechrest, L. J. (2007), Privately Funded and Built U.S. Warships in the Quasi-War of 1797-1801. The Independent Review, (XII), Summer, 101-113.

Secretary Napolitano Announces Deferred Action Process for Young People Who Are Low Enforcement Priorities, (June 15, 2012), https://www.dhs.gov/news/2012/06/15/secretary-napolitano-announcesdeferred-action-process-young-people-who-are-low

Smith, Sam B., Chappell Owsley, Harriet, eds., The Papers of Andrew Jackson, Volume I, 1770-1803,(1980), The University of Tennessee Press.

Spencer, John, ed., 'George Kremer to Andrew Jackson' Correspondence of Andrew Jackson, (1825), http:// www.loc.gov/resource/maj.010650299_0301

Snow, S. (May 7, 2017). Syrian Kurds are now armed with sensitive US weaponry, and the Pentagon denies supplying it, Military Times, https://www.militarytimes.com/news/your-military/2017/05/07/syrian-kurdsare-now-armed-with-sensitive-us-weaponry-and-the-pentagon-denies-supplying-it/

Statement from President Donald J. Trump, (September 5, 2017), https://www.whitehouse.gov/briefingsstatements/statement-president-donald-j-trump-7/

Statement on the Appointment of Dana Boente as Acting Attorney General, (2017), The White House, https:// www.whitehouse.gov/briefings-statements/statement-appointment-dana-boente-acting-attorney-general/

Stepman, Jarrett, (2017), Trump Should Model His Foreign Policy After Andrew Jackson, National Interest, https://nationalinterest.org/feature/trump-should-model-his-foreign-policy-after-andrew-jackson-19771

Tekdal-Fildiş, A . (2018). New role for religion in american politics: How the evangelical church is shaping the middle-eastern politics in particular in the 1sraeli palestinian conflict. İstanbul Üniversitesi Siyasal Bilgiler Fakültesi Dergisi , 27(2) , 149-161 . Retrieved from https://dergipark.org.tr/tr/pub/iusiyasal/ issue $/ 41425 / 500564$

The Office of the U.S. Trade Representative. (2018). United States-Mexico-Canada Agreement, https://ustr.gov/ trade-agreements/free-trade-agreements/united-states-mexico-canada-agreement

The Paris Agreement Under the United Nations Framework Convention on Climate Change, https://unfccc.int/ process-and-meetings/the-paris-agreement/the-paris-agreement

Thomas, R. C. (1976). Andrew Jackson Versus France American Policy Toward France, 1834-36. Tennessee Historical Quarterly, (35), 51-64. 
Thornton, R. (1992), The Cherokees: A Population History, Lincoln: University of Nebraska Press.

Trade Expansion Act of 1962, https://www.govinfo.gov/content/pkg/STATUTE-76/pdf/STATUTE-76-Pg872.pdf Treaty of Amity and Commerce between Siam and the United States, https:/ipfs.io/ipfs/ QmXoypizjW3WknFiJnKLwHCnL72vedxjQkDDP1mXWo6uco/wiki/Siamese-American_Treaty_of_ Amity_and_Commerce.html

Trump targets $\bar{C}$ China trade, says plans serious measures, Reuters, (2016), https://www.reuters.com/article/ususa-election-trump-china-idUSKCN10Z2JN

Trump v. Hawaii. (2017). Supreme Court of the United States, https://www.supremecourt.gov/ opinions/17pdf/17-965 h315.pdf

Tunçdemir, C. (2013). ABD ve Kızılderililer Ilişkisinin Kısa Tarihi, Amerika Bülteni,, http://amerikabulteni. com/2013/12/13/abd-ve-kizilderililer-iliskisinin-kisa-tarihi/

Valentine, A. (2018). Andrew Jackson and the Indian Removal Act of 1830 personal agenda or territorial expansion. Scholarship \& Creative Works, (1), 3-33.

Williams, A., \& Narayanswamy, A. (January 25, 2017), How Trump has made millions by selling his name. The Washington Post, https://www.washingtonpost.com/graphics/world/trump-worldwide-licensing/

Wong, C. V. (2018). The Stakes in the US-China Trade War, Mayer Brown Consulting Trade Alert, 1-4, https:// www.mayerbrown.com/en/perspectives-events/publications/2018/07/the-stakes-in-the-us-china-trade-war

Yarger, H. R., (2015). Building Partner Capacity, Joint Special Operations University Report, 15-1.

Yoo, J. (2008). Andrew Jackson and Presidential Power, Charleston Law Review, (2), 101-152.

Young, S. B. (2003). Two Yankee Diplomats In 1830's Siam, http://www.orchidbooks.com/book_reviews/ two_yank_dips.html 


\section{EKLER}

TABLO - 1

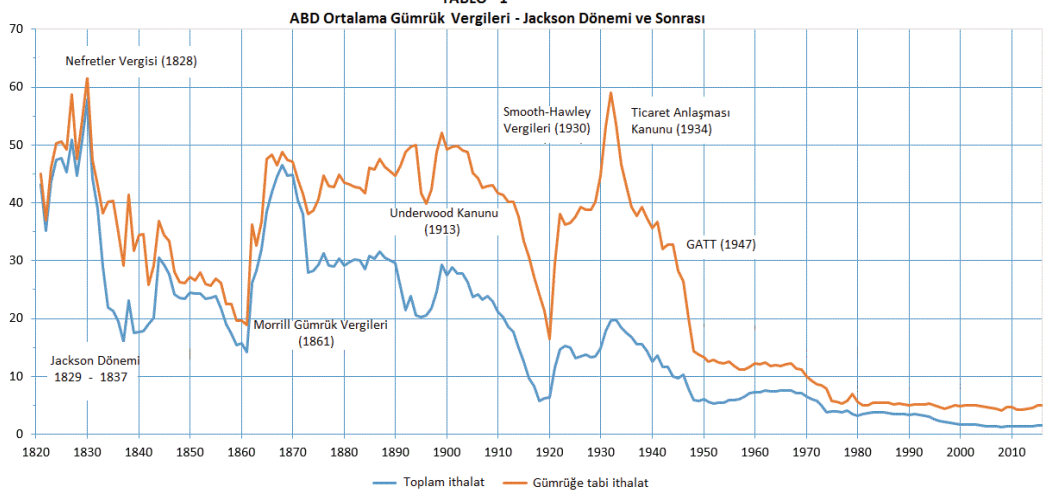

Kaynak: ABD Ticaret Bakanlığı, 2018

TABLO - 2

Trump Yönetiminde Gümrük Vergi Artışı - 2018

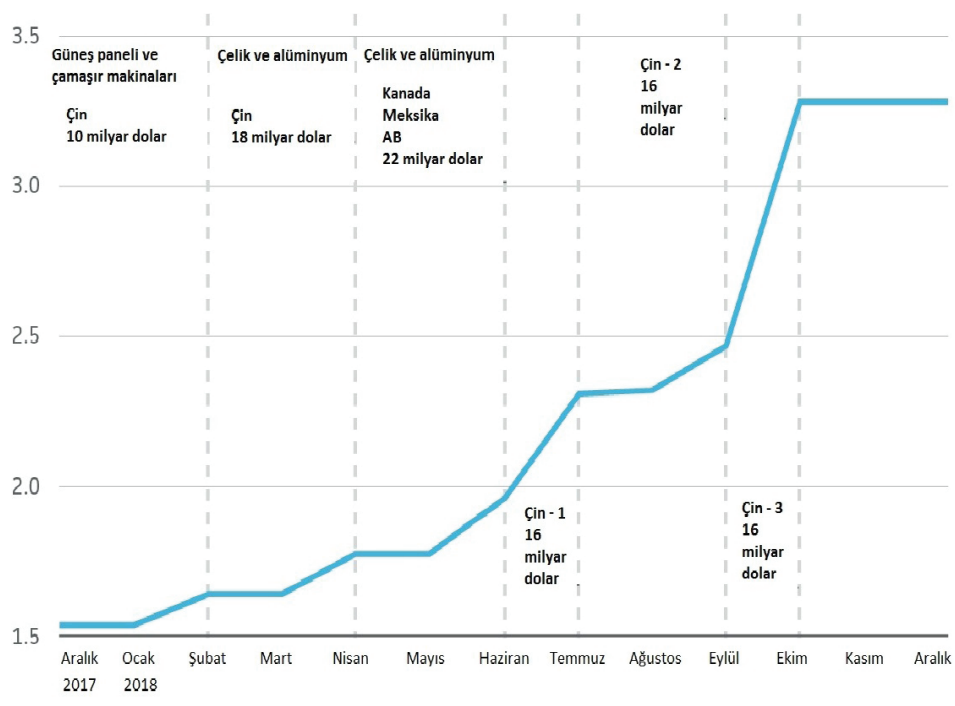

Kaynak: ABD Ticaret Bakanlığı, 2018 
